\title{
Combining New Institutionalisms: Explaining Institutional Change in American Property Insurance
}

\author{
Marc Schneiberg $^{1}$
}

This article combines institutionalisms to explain fundamental change in American property insurance. During the 1950s, the industry shifted from associations to price-competitive markets and vertically integrated firms. I advance two new arguments to explain this shift: First, institutions endogenously generate conditions for change. Second, fundamental change or institutional replacement depends on a dynamic convergence of conditions-market failures, legitimacy crises, new models of order-and the culmination of this dynamic in politics and policies that admit alternatives into fields. Together, these arguments reduce indeterminacies in existing theories of change and shed new light on punctuated equilibria and the politics of transformation.

KEY WORDS: institutional change; market failures; legitimacy; associations; insurance.

Why and how do institutions change? These questions await comprehensive answers, yet scholars have pursued two promising new institutionalist agendas. One approach is economistic: Institutions emerge to produce collective goods or capture rents, to reduce uncertainty in exchange, and to safeguard actors from opportunistic trading partners. Institutions change when new economic conditions fuel market failures or shifts in relative prices, creating gains from new schemes that exceed the costs of organizing collectively to implement them. And while competition may promote efficient alternatives, the outcome of change depends on the payoffs to transformation and the collective-action capacities of interested groups

${ }^{1}$ Department of Sociology, Reed College, Portland, Oregon 97202; e-mail: marc.schneiberg@ reed.edu. 
(Akerloff, 1970; Greif, 1998; Hechter, 1987; North, 1990; Ostrom, 1990; Weingast and Marshall, 1988; Williamson, 1985; Wilson, 1980).

A second approach is cultural and social-constructionist: Institutions enact models of order. They change when external shocks spark controversies that subvert the taken-for-granted character of existing systems and when new models diffuse across fields, providing challengers with rhetorical tools for delegitimating regimes. And while problems affect results, the outcome ultimately depends on networks, state policies, and challengers' ability to transpose templates, mobilize resources, and theorize alternatives in ways that articulate with prevailing moral sentiments (Davis et al., 1994; DiMaggio and Powell, 1983; Dobbin and Dowd, 2000; Edelman, 1990; Fligstein, 1996; Haveman and Rao, 1997; Meyer et al., 1997; Schneiberg and Clemens, 2005).

To date, rational-choice analysis and the cultural-organizational alternative have worked independently, producing a wealth of intellectual resources and a marked division of labor in the new institutionalism (Hall and Taylor, 1996; Scott, 1994). Yet, both approaches involve substantial indeterminacy in explaining change. First, institutionalists have not systematically addressed when and why market failures or new models generate politics or policies of fundamental change that displace extant systems with new arrangements rather than incremental changes that extend the logic of existing institutions. Debates over path-dependence focus on the character of change, pitting claims about evolutionary change and hybrids against images of transformation as a discontinuous succession of regimes (Campbell, 2004; Crouch and Farrell, 2004; Orren and Skowronek, 1994; Streeck and Yamamura, 2003). Yet scholars have just begun to specify the conditions under which fundamental versus incremental change occurs (Greenwood and Hinings, 1996). Second, scholars in both camps generally neglect endogenous sources of change, that is, how existing institutions generate conditions for change. Instead, they invoke external jolts as the force behind failures, price shifts, or the rise of new models, elaborating histories of change as exogenous shock, crisis, and destabilization, followed by the rise of a new system (Oliver, 1992; Schneiberg and Soule, 2005; but see Edelman et al. 1999; Leblebici et al., 1991). In so doing, institutionalists treat the source or initial impetus for change descriptively, in an ad hoc manner, as outside the paradigm.

I document and address these indeterminacies by analyzing American property insurance, an anomaly for existing theory. From 1860 to 1950, insurers faced incentives and market failures that drove other U.S. industries to price-competitive markets and vertically integrated firms. Insurers also attracted controversy, especially after 1880 , as states subjected insurance industry practices to hostile scrutiny and antitrust policies, subverting their 
legitimacy. Despite these conditions for a shift to markets and corporations - and departing dramatically from common practice-insurers committed themselves instead to association and price control as their central governance logic, managing market failures and the like through incremental changes that elaborated this logic. In fact, insurers did not meet market failures or legitimacy crises with vertical integration and pricecompetitive markets until the 1950s, when "direct writers" like Allstate and State Farm rose to dominance, sparking fundamental change.

This absence of change where expected, followed by a rapid, fundamental shift, evokes the imagery of punctuated equilibrium (Krasner, 1984), and forms the basis for a critical case study that addresses indeterminacies in prior research. Using historical analysis, I aim to construct, rather than test, theory, using the strengths of a case study approach. In-depth studies of well-chosen cases are especially useful for tracing how actors define problems and solutions, how contexts shape problem solving, and how unexpected outcomes emerge (Snow and Anderson, 1991; Yin, 1994). Moreover, the insurance case is ideally suited for building theories of institutional change. It provides both a puzzle for prior work, highlighting its key shortcomings, and a natural experiment, letting us compare periods of incremental and fundamental transformations in order to craft new theory about change.

Parts 1 and 2 introduce the case and relevant theory, describing the two systems that prevailed in property insurance and deriving expectations from prior work about the shift from one to the other. In parts 3 and 4, theory confronts case and is found wanting. In part 3, I focus on the 1860s through the 1940s. I show, first, how conditions for change were created in and by existing institutions and, second, how the industry met failures, controversies, and shocks via incremental changes that extended and reproduced associations. Conditions highlighted by existing theory failed to produce the expected qualitative shift for nearly eight decades. In part 4, I document the forces and sequence of events that fostered the shift to pricecompetitive markets and vertically integrated firms in the 1950s and early 1960s. Part 5 returns to theory, using the comparison between the two periods and patterns to theorize the endogenous sources of change and the conditions for fundamental versus incremental transformation.

\section{CASE AND CONTEXT: INSTITUTIONAL CHANGE IN PROPERTY INSURANCE}

For much of its history, the property insurance business pursued association and independent distribution as its central governance logic, 
elaborating association to solve new problems. Yet after 1950, the field embraced price competition and vertically integrated firms, sparking fundamental change. Table I and the following discussion outline the two systems, providing the outcome and empirical context for engaging theories of change.

\section{Associations and Agents}

Before 1950, American property insurance embraced three organizing principles. ${ }^{2}$ First, companies distributed insurance via networks of independent agents (Hanson et al., 1974; Joskow, 1973; Kimball and Jackson, 1961; Mehr, 1969; Oviatt, 1905). This "American agency system" arose in the pre-Civil War era as companies expanding beyond their home cities turned to agents and brokers to solicit clients, assess risks, sell policies, and settle claims. Agents and brokers were independent distributors, represented 4-12 insurers, and received commissions when they placed or renewed policies.

Second, companies and agents governed insurance collectively, through private associations (Parker, 1965; Riegel, 1916; Schneiberg, 1999; Wandel, 1935; see Streeck and Schmitter, 1985, for a general treatment). Associations first appeared in the 1820s, as companies and agents organized local compacts or boards to control markets in a city or town. But in the post-Civil War decades, insurers supplemented and then incorporated local boards within state, regional and national bodies, forging a nationwide system of more than 1,000 associations. This system of associations was the central vehicle for governing the sector through 1950, regulating both final market transactions with consumers and intermediate market transactions between companies and agents. Associations set premium rates and policy forms, pooled loss data, formed inspection boards, created

\footnotetext{
${ }^{2}$ The American property insurance field encompasses the providers, professionals, private bodies, and state actors involved in: (1) insuring property and its owners against damage, accident, and loss, and (2) regulating or supporting insurance provision. As DiMaggio and Powell (1983) note, a field is broader than an industry or collection of firms, suppliers, and consumers. Yet analyses of sector governance commonly construe "industry" broadly to include regulators and other relevant actors, converging on a field conception (Campbell et al., 1991; Hollingsworth et al., 1994). In the United States, property insurance was segregated from life insurance by laws requiring firms to specialize in one or the other, constituting property insurance as a distinct economic field. This field contains various insurance lines, which were collectively represented through the 1920 s by fire insurance. Fire insurance covers fire, storms, and an array of "allied perils," and was the leading line in the field, both for its size and its role as an exemplar or site where settlements and models for the field were established. After the 1920s, fire coverage was increasingly folded into homeowner, commercial multiperil, and automobile lines. For purposes of exposition, this paper uses property insurance industry or field interchangeably to denote the entire field, its core logics, and central tendencies.
} 
Table I. Institutional Systems in American Property Insurance

\begin{tabular}{|c|c|c|}
\hline & $\begin{array}{l}\text { Association and state rate } \\
\text { regulation, ca. } 1860 \mathrm{~s}-1940 \mathrm{~s}\end{array}$ & $\begin{array}{l}\text { Mass consumer markets } \\
\text { and vertically integrated } \\
\text { firms, ca. } 1950 \text { s-present }\end{array}$ \\
\hline General character & $\begin{array}{l}\text { Relatively decentralized mix of } \\
\text { local companies, national } \\
\text { general insurers, and } \\
\text { independent agents governed } \\
\text { by a system of national, } \\
\text { regional, and local } \\
\text { associations. }\end{array}$ & $\begin{array}{l}\text { Price-competitive strategies and } \\
\text { vertically integrated direct } \\
\text { writers introduce a } \\
\text { mass-market, large-firm } \\
\text { system of corporate } \\
\text { hierarchies into property } \\
\text { insurance. }\end{array}$ \\
\hline $\begin{array}{l}\text { Intermediate market } \\
\text { (company-agent) } \\
\text { transactions }\end{array}$ & $\begin{array}{l}\text { Association and agency system } \\
\text { - Distribution via } \\
\text { independent agents and } \\
\text { brokers } \\
\text { - Companies associate to } \\
\text { control commissions, } \\
\text { license brokers. } \\
\text { - Agents associate to control } \\
\text { territory and } \\
\text { representation, and } \\
\text { coordinate rate-making, } \\
\text { etc., with companies. }\end{array}$ & $\begin{array}{l}\text { Corporate hierarchy } \\
\text { - Vertical integration } \\
\text { bypasses independent } \\
\text { middleman. } \\
\text { - Direct writers subject } \\
\text { agents to direct } \\
\text { bureaucratic controls. } \\
\text { - Displaces association and } \\
\text { subjects remaining } \\
\text { independent agents to } \\
\text { competitive pressure. }\end{array}$ \\
\hline $\begin{array}{l}\text { Final market } \\
\text { (company- } \\
\text { consumer) } \\
\text { transactions }\end{array}$ & $\begin{array}{l}\text { Association and regulated } \\
\text { cooperation } \\
\text { - Associations fix rates and } \\
\text { rate schedules, create } \\
\text { uniform classifications and } \\
\text { policy forms, pool data, } \\
\text { inspect risks. } \\
\text { - Bargain collectively with } \\
\text { consumers groups and } \\
\text { officials over rates, } \\
\text { prevention, etc. } \\
\text { - Overlaid beginning in the } \\
\text { 1910s by state } \\
\text { rate-regulation laws that } \\
\text { authorize and regulate } \\
\text { association. }\end{array}$ & $\begin{array}{l}\text { Price-competitive markets } \\
\text { - Direct writers, } \\
\text { independents, and } \\
\text { regulators pursue/ } \\
\text { permit independent } \\
\text { pricing and market } \\
\text { competition in most lines. } \\
\text { - Leading firms rely on their } \\
\text { own loss data, risk } \\
\text { classification, inspection } \\
\text { services. } \\
\text { - Associations and insurance } \\
\text { commissioners relegated } \\
\text { to a secondary, advisory } \\
\text { status in rate-making. }\end{array}$ \\
\hline
\end{tabular}

risk classifications, and bargained collectively with consumers and officials over the terms and standards of trade. They also governed distribution and the agency system: companies associated to license brokers and fix commissions, and agents formed boards to fix rules for representation and territory.

Third, states subjected associations to public oversight: 33 states passed rate-regulation laws between 1909 and 1928 (Meier, 1988; Rose, 1967; Schneiberg and Bartley, 2001). These laws institutionalized "regulated cooperation." They enacted a quid-pro-quo in which consumers and lawmakers ratified associations, granting insurers legal rights to fix rates, in exchange for insurers' submitting rates and associations to public 
supervision, disclosure rules, and appeals. They also ratified a boundary between insurance, an infrastructure sector producing a public good, and "ordinary trades," where price competition and antitrust laws were appropriate.

This system was resilient. From 1860 through the 1940s, associations and cooperative rate-making coexisted with the American agency system, acquiring a regulatory overlay in the 1910s. Price competition was limited, and vertical integration was virtually nonexistent.

\section{Price-Competitive Markets, Vertically Integrated Hierarchies}

After 1950, rapid and fundamental change occurred (see Table I, column 2). First, after decades of insulating insurance, states and industry members began to blur the boundaries between insurance and "ordinary trades" by introducing price competition. Limited in scope and intent, these polices aimed to improve, not displace, associations by granting firms some leeway to set their own rates and pressuring bureaus to reduce rates. Nevertheless, they gave price competition a foothold in the sector, inadvertently fueling dynamics that pushed associations toward the margins.

Second, vertically integrated insurers rose to dominance, as firms like State Farm moved into distribution, bypassing independent agents to deal directly with insureds. These firms attacked the independent agent and were a force for price competition. "Direct writing" eliminated the independent middleman-his commissions and hold over distribution-and subjected risk selection and claims to direct control, translating reduced commissions and claim costs into lower prices and increased market share. Indeed, using vertical integration to break agents' hold over distribution proved decisive for firms' efforts to breach boundaries around insurance. Lower commissions and claims let direct writers cut prices by $10-40 \%$, capturing nearly half the homeowners' market and over $60 \%$ of private passenger automobile insurance (Etgar, 1976:486; Joskow, 1973:405; Lusk and Hibbard, 1981; Meier, 1988:9-10).

This shift did not completely drive associations or independent agents from the field. ${ }^{3}$ Yet it fundamentally transformed property insurance, bringing a mass-market, large-firm system to a sector that had been a more

\footnotetext{
${ }^{3}$ Company associations and insurance commissioners continue to play a role in generating standards, advising rate makers, and governing the industry in many locations. States like Texas and New Jersey, and lines like workers' compensation, have resisted change (Hartman, 1972; Meier, 1988). Numerous independent agents are still present, although they have lost exclusive control over distribution, have been relegated to secondary status in leading insurance lines, and have found their commissions dramatically reduced by competition from direct writers.
} 
decentralized mix of associations, bureau companies, independent distributors, and local firms. In final markets, cooperative rate-fixing gave way to independent pricing and market competition as central regulating principles, and leading firms came to rely on their own loss data, risk classifications, and inspection routines. In intermediate markets, corporate hierarchy came to play a central governance role. As direct writers brought distribution "inside" the firm, they subjected transactions to direct bureaucratic control, forcing associations almost completely out of this domain.

To explain this shift, we turn first to existing theory for expectations about the conditions, mechanisms, and sequence of events involved. Prior work yields substantial insight, identifying market failures, legitimacy crises, and other conditions that were critical in the insurance case. But in ways not anticipated, these conditions for change were created by the existing system. And contrary to expectation, market failures and crises did not yield the anticipated fundamental change, but produced instead 80 years of incremental transformation.

\section{EXPLAINING INSTITUTIONAL CHANGE - EXISTING APPROACHES}

Existing work provides arguments about both the conditions for wholesale change and its sources or initial impetus. Table II focuses on conditions for change, presenting explanations derived from prior work for the fundamental shifts observed in the insurance case.

\section{Conditions for Change}

From rational-choice scholars come analyses of institutions as problem-solving devices that actors use to induce stability, contain opportunism, and realize gains from cooperation or trade (Ingram and Clay, 2000; North, 1989; Weingast and Marshall, 1988). Such analyses explain institution-building and change as responses to two kinds of problems or market failures: the bilateral, exchange-based problems of negotiating and enforcing agreements (Arrow, 1963; Heimer, 1985; Williamson, 1975) and the multiactor problems of producing collective goods (Olson, 1971; Ostrom, 1990). They also stress the costs and benefits of institutions and their incidence across groups. New systems arise as problems or price shifts alter the incentives and bargaining power of groups, disrupting equilibria and producing payoffs to alternatives that exceed the costs of organizing for change (Greif, 1998; Knight, 2001; North, 1981). 
Table II. Existing Theories of the Conditions for Price-Competitive Markets and Vertically Integrated Firms

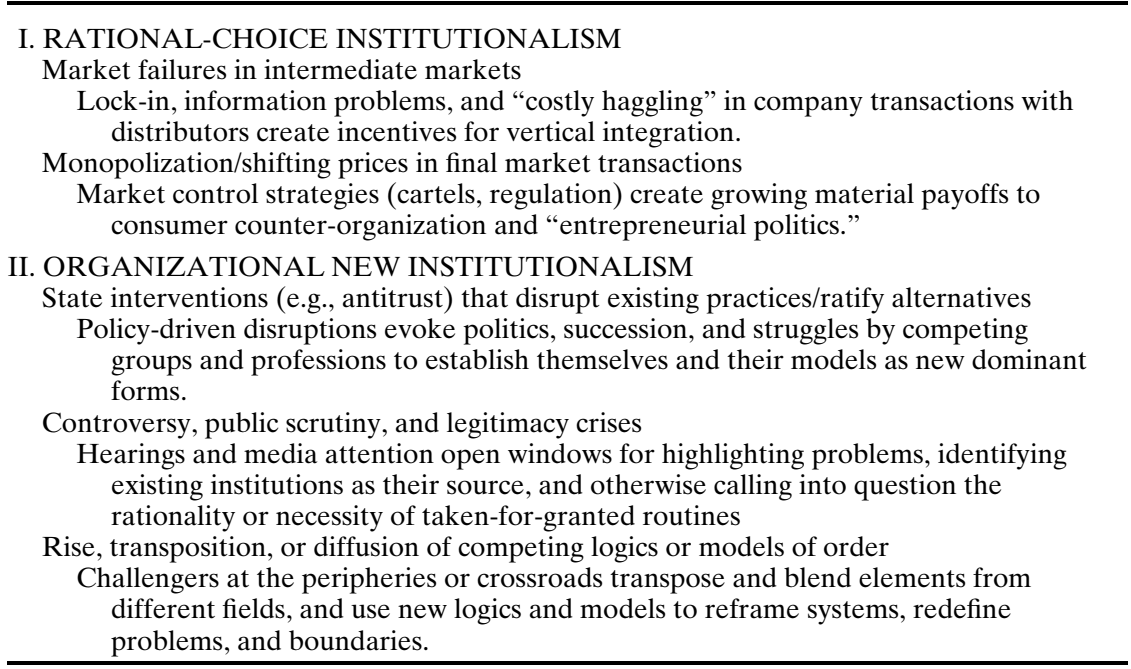

For rational-choice theories of the mass-production corporation, intermediate market failures would explain the rise of vertically integrated firms in the insurance sector (Anderson, 1985; Anderson and Schmittlein, 1984; Chandler, 1977; Grossman and Hart, 1986; Klein et al., 1978; Monteverde and Teece, 1982; Williamson, 1975). Firms often handle volume production via market exchanges with independent distributors and suppliers, using monitoring, contract terms, and threats to switch business to competitors to check opportunism. But market safeguards can fail. Monitoring performance or product quality can be costly, and the costs of exiting a transaction and switching contractors can increase, leaving firms "locked in" to an exchange (Alchian and Demsetz, 1972; Alchian and Woodward, 1988; Williamson, 1985). ${ }^{4}$ Firms in these circumstances become vulnerable to malfeasance, strategic behavior, and expropriation by trading partners ("hold-up" and "moral hazard costs"), and must invest in negotiating and litigating contracts ("costly haggling"). These conditions, in turn, give firms incentives to vertically integrate. By acquiring suppliers' or distributors' assets, and subjecting these actors to direct monitoring and the employment relation, a firm can limit the ability of suppliers or distributors to act at the firm's expense (but see Freeland, 2000).

\footnotetext{
4 "Lock-in" and other failures can stem from product characteristics or interdependencies between activities that make evaluation difficult, reliance on personal ties in distribution or supply, and transaction-specific investments whose value can only be fully realized in association with a particular supplier or distributor.
} 
Analyses of regulation and cartels offer a second account, positing monopolization and shifting payoffs in transactions with consumers as the key conditions for change (Bowman, 1989; Noll, 1989; Olson, 1971; Peltzman, 1989; Stigler, 1971; Wilson, 1980). Firms use cartels or regulation to limit competition and can succeed, at first, due to asymmetries in the benefits and costs of market control: Where benefits are concentrated among a few homogenous, often geographically proximate firms with high stakes in the regulated transaction, the costs (high prices) are distributed across numerous, diverse, and dispersed consumers with low per-capita stakes in that transaction. At the outset, market control is a "collective bad" borne by groups with few capacities for collective action. Yet, in forging cartels or capturing regulators, firms alter relative prices for large numbers of consumers, creating diffuse but, in the aggregate, substantial payoffs for counterorganization. Such payoffs can fuel collective action among privileged consumer groups or "entrepreneurial politics" (Peltzman, 1976; Wilson, 1980), in which aspiring politicians mobilize diffuse interests by helping them to organize or supplying pro-competition policies. Thus, such analyses would explain the shift to direct writing and competitive markets as a result of (1) intermediate market failures in insurers' transactions with agents, or (2) shifting prices and market control in final market transactions.

In contrast, organizational institutionalists stress politico-cultural dynamics, public policy, and legitimacy processes, viewing institutions as embodiments of taken-for-granted or rationalized models of order (Dobbin, 1994; Meyer et al., 1997). This research suggests that state interventions that prohibit or ratify existing systems or alternatives might account for the shifts observed in insurance (Campbell and Lindberg, 1990; Edelman, 1990; Fligstein, 1990; Kelly, 2003). Interventions range from ambiguous legal mandates to rules that ban specific practices, and they gain force as professions or courts theorize new models as rational or efficient. But endorsements aside, state action can decisively disrupt existing arrangements, evoking politics, claims-making activities, and a succession of players and forms, as competing groups and professions struggle to redraw boundaries and establish themselves and their models as a new dominant force. In fact, antitrust policies against corporate combinations have been a key condition for change in the U.S. economy (Fligstein, 1990; Schneiberg and Hollingsworth, 1990).

Alternatively, change can flow from controversy, public scrutiny, or debates that subvert the legitimacy or taken-for-granted character of existing systems (Baumgartner and Jones, 1991; Derthick and Quirk, 1985; Hoffman, 1999; Oliver, 1992; Schneiberg and Bartley, 2001; Sine and David, 2003; see also Kingdon, 1984). Scrutiny and debate can emerge from various sources and in different venues, including hearings, legislative 
investigations, court cases, conferences, trade journals, and the popular press. Once underway, they become platforms or widows for focusing attention on problems, identifying existing institutions as their source, introducing new analyses or alternatives into the debate, and otherwise calling into question the rationality or necessity of existing arrangements for policymakers and key publics. And to the extent that hearings or media attention spread perceptions of scandal, crisis, or irrationality, they can profoundly reshape policy environments, enabling experts and challengers to contest long-standing institutions and their entrenched, vested interests.

Finally, change can result from the rise, transposition, and diffusion of competing logics or new models of order within fields (Davis and Greve, 1997; Freidland and Alford, 1991; Geenwood and Hinings, 1996; Scott et al., 2000; Strang and Soule, 1998; Thornton, 2002). Diffusion or mimesis is a central mechanism of change. Yet recent work emphasizes competing logics and models, overlaps or breaches of boundaries between fields, and the mobilization of coalitions around new models (Edelman et al., 2001; Morrill, 2005; Rao, 1998; Schneiberg and Soule, 2005; Stryker, 2000). Change occurs as challengers, working at the peripheries or crossroads, transpose or blend elements from different fields and use new models or forms to reframe systems, redefine problems and boundaries, and gain entry into established regimes (Abolafia, 1996; Clemens, 1997; Heimer, 1999; Kleinman and Vallas, 2001; Stearns and Allen, 1996). Thus, organizational analysts would explain the shift in insurance to competitive markets and direct writing as a result of (1) acts by states and professions, like antitrust policies, that disrupt associational governance or ratify alternatives; (2) legitimacy crises that subject associations to public scrutiny and debate; or (3) the transposition and diffusion in the industry of new or competing models of order.

\section{Sources of Change}

Prior work also provides expectations about the source of change. With few exceptions, rational-choice and organizational institutionalists routinely invoke exogenous shocks as the source or initial impetus for fundamental transformations and the controversies or price shifts that produce them.

While we might expect differences by approach, ${ }^{5}$ scholars in both camps attribute the trigger for change to external shocks or price shifts,

\footnotetext{
${ }^{5}$ Where organizational analysts often emphasize environments as causal forces, foregrounding external factors, rational-choice scholars stress market failures internal to an industry. Notably, exceptions to the norm of citing exogenous factors also come from both the organizational (Abolafia, 1996; Edelman, in press; Edelman et al., 1999; Leblebici et al., 1991) and the rational-choice sides of the aisle (Greif, 1998; North and Weingast, 1989; Peltzman, 1989).
} 
including technology (Barley, 1986; North, 1981), demography (Haveman and Rao, 1997; Levi, 1998), oil shocks (Sine and David, 2003), environmental disaster (Hoffman, 1999), strikes (Meyer, 1982), shifts in markets, wealth, or policy (Campbell and Lindberg, 1990; Fligstein, 1990; Ingram, 1998; Knight and Ensminger, 1998; Rao, 1998), depression (Chandler, 1977; Skowronek, 1982), or the end of the cold war (Bates, 1998). Indeed, this stance defines expectations about not only the source of fundamental change, but also its trajectory, outlining a history of change as exogenous shock or disruption, followed by contestation and deinstitutionalization, reinstitutionalization, and the consolidation of the field around new logics or forms.

This stance stems partly from observations that fundamental change is often triggered by external shocks. But it is also rooted in arguments about path-dependence and institutions as bases of stability and order (Crouch and Farrell, 2004; Ingram and Clay, 2000; Orren and Skorownek, 1994). Actors who respond to market failures, controversies, and the like are typically embedded in institutions-systems that entail sunk costs, create vested interests, bound rationality in taken for granted cognitive frames, and channel problem-solving along paths that are consistent with existing routines (Dobbin, 1994; Hollingsworth, 1997; North, 1990; Thelen and Steinmo, 1992). Actors are also subject to isomorphic pressures to conform to typical practices, whether from peers, regulators, professions, consultants, or expert communities (DiMaggio and Powell, 1983; Edelman, 1990). They may even find their problem-solving efforts constrained by interlocks, complementarities, or positive feedbacks among elements of established systems that make it hard to transpose new solutions piecemeal into existing configurations (Djelic, 1998; Hall and Soskice, 2001; Hollingsworth, 1997). Thus, problem-solvers usually pursue incremental change, extensions of existing logics, or hybrids at the margins (Campbell, 2004; Streeck and Yamamura, 2003; Thelen, 1999). In contrast, fundamental change requires that extant systems first undergo exogenous shocks that disrupt existing routines, interests, and understandings, enabling or even forcing states or organizations to pursue new paths (Hoffman, 1999; Meyer, 1982; Sine and David, 2003).

The following sections apply these arguments about change to explain the shift in insurance from associations to price-competitive markets and vertically integrated firms. In key respects, this shift is just what prior research would expect. Firms faced the market failures that theories of vertical integration emphasize. Consumers and states faced shifting prices in final market transactions. The associational system was subject to legitimacy crises, controversy, and even trust-busting policy shocks. Yet in ways not expected by prior research, the existing system generated failures, controversies, and legitimacy crises. And contrary to expectation, failures, 
controversy, and shocks did not yield the anticipated shift to competitive markets and vertically integrated firms. Instead, they produced decades of boundary maintenance and incremental change, sparking fundamental transformations only after the 1940s. As we shall see, prior accounts suffer from substantial indeterminacy regarding both the source of change and the conditions for fundamental transformation.

Part 3 examines the genesis and outcomes of market failure, controversy, and legitimacy crises in U.S. property insurance, tracing their endogenous production and their failure to produce fundamental change from the 1860s through the 1940s. Part 4 traces the onset of the shift to pricecompetitive markets and corporate hierarchies beginning in the late 1940s, creating a comparative basis for building theory about the conditions and sources of fundamental change.

\section{MARKET FAILURE, CONTROVERSY AND INCREMENTAL CHANGE, 1860-1940}

To understand both the endogenous production of conditions for change and the types of change those conditions produced, I turn first to the association system in insurance and the mechanisms of its construction and reproduction. These form the context from which conditions for fundamental change emerged - and failed to produce the anticipated result.

\section{Baseline Institutions}

Associations in insurance rested on a conjunction of problem-solving, legitimating models, coalitions, and jurisdictional settlements. Insurers associated in the nineteenth century to solve two problems of competition. Competition led firms to underproduce a key collective good: pooled loss data (New York State, 1911 ("Merritt Report"); Wandel, 1935). Insurance firms were small and had to pool data on losses in order to use the laws of large numbers to eliminate uncertainty and estimate loss costs. But data on insureds had competitive value, so firms hoarded information, depriving themselves of good cost data. Moreover, competition fueled price wars that drove rates below actuarially sound levels (Kimball and Boyce, 1958; Oviatt, 1905; Zartman, 1909). Insurance markets were prone to excess price warfare because companies lacked good cost data, and because losses were concentrated in rare events like the Chicago fire, enabling firms to take business and pay dividends at unsound rates. But rate wars routinely depleted firms' reserves. And after conflagrations, insurers failed in droves 
(Kimball and Boyce, 1958; Parker, 1965), driving companies and agents to form associations and pool data.

Vital for this effort was a model of the insurance market as a scientifically administered, quasi-public market (Schneiberg, 1999). Codified by New York's so-called Merritt Committee, this model cast cooperative pricefixing as the sector's salvation, drawing a boundary between insurance, an infrastructure sector producing a public good, and "ordinary trades," where price competition and antitrust regulation were appropriate. In this view, insurance was a "tax" that pooled community resources, covering the losses of the few via small "tariffs" on the many (Dean, 1901; New York State, 1911). Tariffs must be sufficient to cover losses and justly allocated. Companies should assess an individual or risk class "upon its own merit," that is, in proportion to the losses it imposes on the community, so that the prudent paid low rates, and the careless paid high rates. But rate wars drove prices below costs and divorced rates from hazards, fueling carelessness and loss. Cooperative pricing was thus needed, advocates argued, to tie rates to costs, check unfair discrimination, protect consumers from insurer insolvency, and induce prevention, a public good.

Cooperative pricing was also needed to ground insurance in actuarial science and statistical analysis. Using life insurance as an exemplar, advocates theorized data pooling and price fixing as ways to create mortality tables for property hazards and to establish a scientific rate-making system run by actuaries and expert inspectors. Moreover, to check monopoly, advocates argued for rate laws and "regulated cooperation," in which states supervised and enforced scientific rate-making.

This conjunction of problems and a legitimating model rested on and helped crystallize coalitions and jurisdictional settlements that sustained associations for more than eight decades. The core coalition pivoted around general insurance companies. These were multistate firms who lost money in rate wars, needed price controls on small risks to offset losses on commercial lines, and sought national rate-making so they could cover losses from conflagrations with premiums from other areas. General insurers organized associations, as did agents, who enforced rate compacts and built winning political coalitions for rate regulation. Agents supported associations to secure their hold over distribution and shield commissions from price pressures. In the 1910s, insurers and agents were joined by rate-regulation states like New York, and by insurance commissioners and actuaries, aspiring professionals who used regulation and scientific rate-making to claim jurisdiction in the sector. States and commissioners acted under authority granted by the U.S. Supreme Court. In decisions dating from 1869, the Court granted states jurisdiction over insurance. In 1914, it ruled that insurance was "affected with a public interest" and upheld states' rights to 
regulate rates, ratifying the line between insurance and ordinary trades. At first, consumer groups favored antitrust laws and price competition. Yet they, too, suffered from market failures, had interests in stable markets, and endorsed association, provided it was regulated by the states and conformed to norms of scientific rate-making.

As problem-solving devices, associations and agents delivered the goods for an extended period. But they also produced the conditions for the shift to competitive markets and vertically integrated firms. First, associations marginalized champions of alternatives, fostering groups interested in challenging the regime. These groups included mutual insurers, who were excluded from rating bureaus, and price-cutting independentslow-cost firms whose success hinged on reducing rates. They also included insurers in Texas and California, states that rejected regulated cooperation and federal antitrust authorities like the Justice Department, which embraced neoclassical economics and price competition, but were kept from intervening by the Supreme Court, which granted states jurisdiction over insurance. In the 1940s, small direct writers appeared on the margins.

Furthermore, associations induced new market failures and price shifts, public scrutiny, and policy shocks, creating material and cultural conditions for the shift to price-competitive markets and vertically integrated firms-decades before it occurred. Table III outlines these conditions and the outcomes they produced.

\section{Endogenous Failures and Price Shifts}

Associations and the agency system fostered two kinds of market failure and price shifts, and linked these failures in self-reinforcing ways. First, associations fueled opportunism in companies' transactions with consumers. Consumers derived benefits from letting insurers stabilize markets. Yet associations allowed insurers to engage in monopoly pricing and discrimination, particularly after they instituted private enforcement schemes in the 1880s. In response, consumers and commissioners worked to contain monopoly via regulation, licensing associations, rate orders, and disclosure rules. But in shielding firms from competition and delegating public powers to private rating bureaus, regulated cooperation increased insurers' capacities for opportunistic collective action, creating a context in which companies could learn how to manage the regulatory system. By the late 1920s and 1930s, companies could manipulate data and classification schemes, delay rate orders via litigation, and subvert safeguards against excessive rates, subjecting consumers to new risks of appropriation (Elmore, 


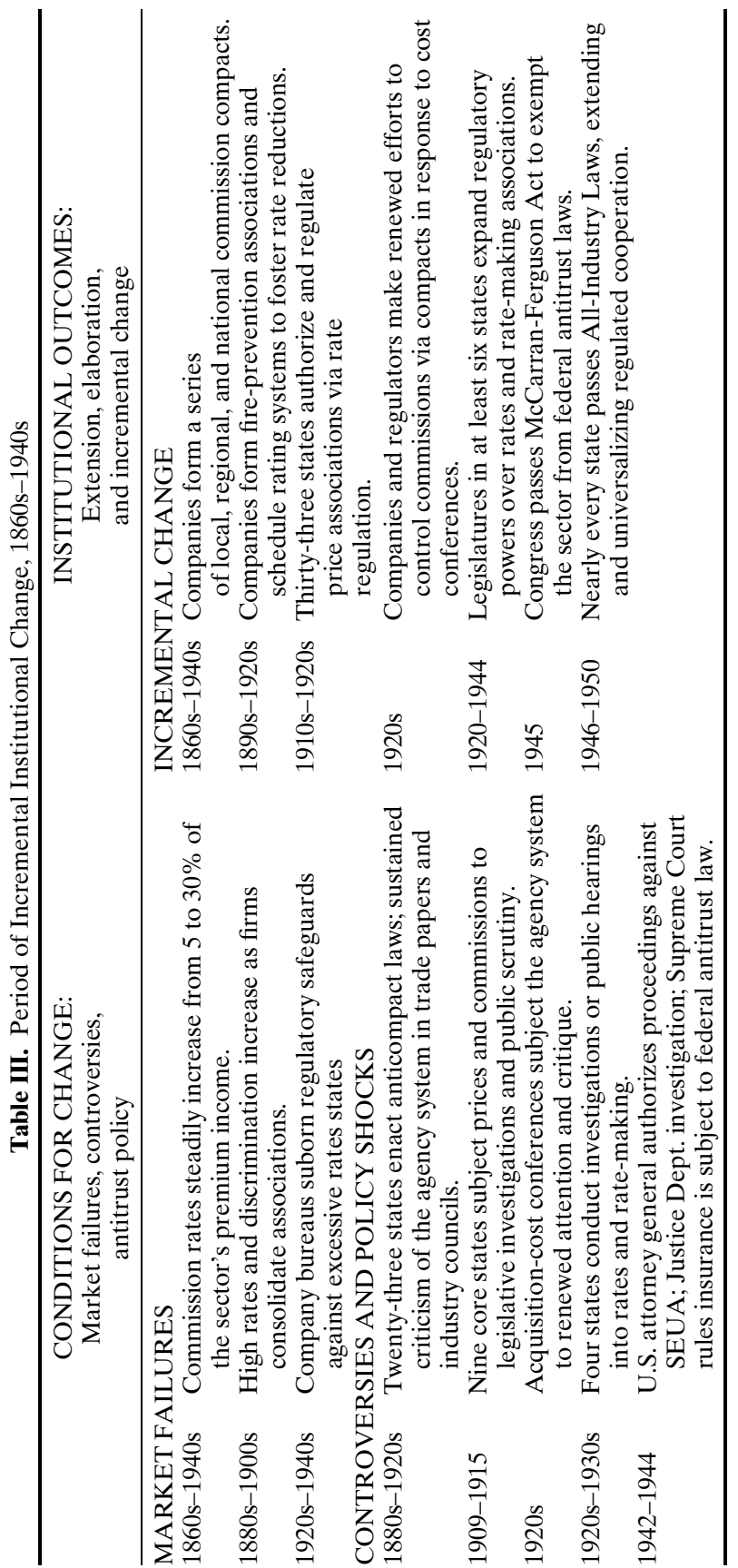


1959; Hobbs, 1942:363-367; Kimball and Boyce, 1958; Lilly, 1976; Meier, 1988:65-67). ${ }^{6}$

Second, associations fueled opportunism in companies' transactions with agents (Etgar, 1976; Hanson et al., 1974:9-11, 516-519; Joskow, 1973; Oviatt, 1905; Wandel, 1935:11-12). As noted, companies relied on independent agents and brokers to solicit clients, assess risks, and sell policies. Agents represented 4-12 firms, received commissions when they placed or renewed a policy, and proved vital to sector growth.

However, this scheme also granted agents broad powers and tied compensation to business volume, but gave agents no stake in selecting risks or reducing loss. Further, the large number of agencies and long distances between agents and company offices made monitoring agents costly. The system thus created a moral hazard: It induced and enabled agents to expand coverage, relax underwriting standards, and misrepresent claims to win consumer favor, increase volume, and generate commissions. Moreover, firms were locked in to the agent who solicited the insured. Initially, companies could access an insured through any agent. But once a policy was placed, agents developed personal ties with insureds and property rights in expirations. Companies could not switch distributors; they had to renew through the originating agent. In contrast, agents could switch a client among companies, holding them up for benefits, like higher commissions.

At first, hold-up costs were small, with commissions of $5 \%$ in the $1850 \mathrm{~s}$. But agents used lock-in and the opportunities created by associations to raise commissions and saddle firms with poor risks and inflated claims. Associations shielded commissions from price pressures, enabling agents to exploit their leverage. In addition, by foreclosing price competition, associations induced nonprice rivalry, in which firms bought business from agents by taking poor risks and raising commissions (Frech and Samprone, 1980; Pauly et al., 1986; Samprone, 1979; Sichel, 1966). Furthermore, associations lifted any real constraint on these rivalries: Price controls let insurers pass commissions and other expenses on to consumers, reducing incentives to solve the agent problem. And by incorporating agents as enforcers and key coalition members, associations granted agents de facto veto power over

\footnotetext{
${ }^{6} \mathrm{~A}$ key measure of firms' pricing capacities is the loss ratio, or the proportion of premiums collected that return to policyholders as losses paid. Systematic data are not readily available, and problems of comparability abound, but investigations and cases suggest ratios of roughly $55 \%$ at the turn of the century and $50 \%$ in 1910 , declining to the low 40 s between 1912 and 1920 in states like New York, where companies were well organized, and falling as low as $34 \%$ in the 1940s in states under the jurisdiction of the SEUA, a bureau notorious for market control (Elmore, 1959:510-511; New York State, 1911:1416-1417 (Exhibit A); 1922:202). Consumers got back progressively less of what they collectively contributed to the insurance pool. In contrast, under price competition, loss ratios rose to $50-60 \%$ by 1967 , and $60-70 \%$ in the following decade (New York State, 1969:124; U.S. Department of Justice, 1977:85-88).
} 


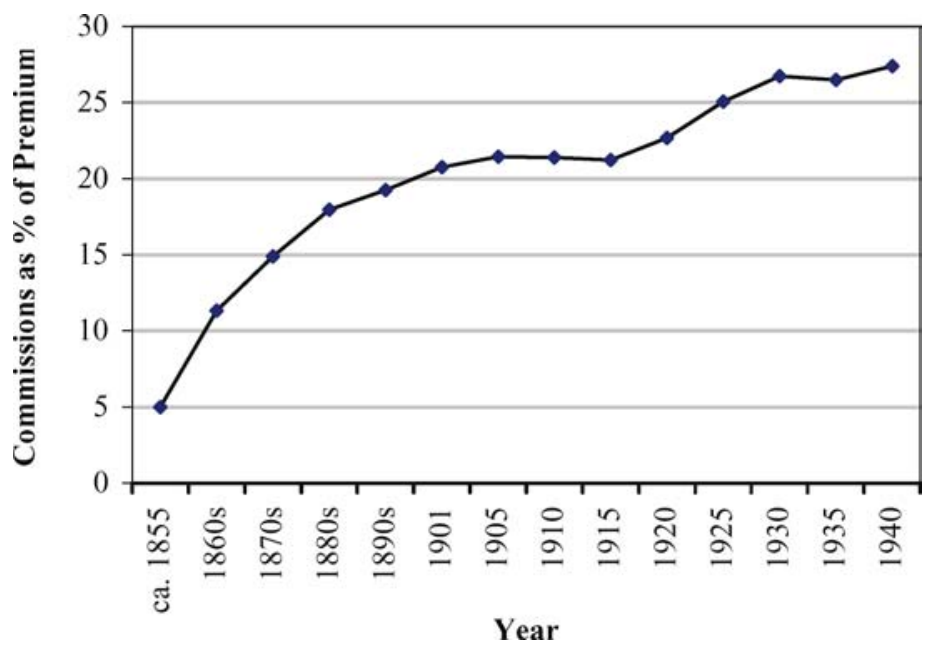

Fig. 1. Commission rates paid by stock fire insurers, 1855-1940.

any effort to bypass them or prevent them from exploiting nonprice rivalries (Bennett, 1955; Whitney, 1958). As Fig. 1 shows, these rivalries drove commissions to four times their 1850 levels by 1900, with agents capturing over a fifth of the sector's premium income. By the 1930s, agents had increased their cut to $30 \%$ of every premium dollar. Here, too, the system itself induced new failures, creating material foundations for a shift to competitive markets and vertically integrated firms.

Indeed, by 1900, publicly enforced price competition and vertical integration were well-recognized solutions for such problems. Competition could break monopoly. Moreover, vertical integration-introducing hierarchy and the employment relation into distribution - could at least partly solve the agent problem (Anderson, 1985; Anderson and Schmittlein, 1984). By binding agents to the firm via employment or exclusive representation contracts, companies could increase their ability to organize and control distribution. They could separate sales from underwriting and claims, tie compensation to careful risk selection and underwriting results, and subject agents to increased reporting requirements and information systems. This would reduce opportunities and incentives for agents to saddle insurers with bad risks and claims. Moreover, in moving into distribution, firms could retain or acquire rights to expirations and force agents to represent only one company, depriving them of their ability to switch clients among firms. In effect, integration could break agents' hold on distribution, letting companies cut loss costs, commissions, and prices. And this was, in fact, 
precisely what direct writers would—eventually—do, once they could contest the associations' hold over prices.

\section{Endogenous Controversies and Policy Shocks}

To be sure, vested interests helped to prevent a shift to markets or integrated firms. Yet associations produced other forces for change. They not only evoked controversy and legitimacy crises that subverted the system's taken-for-granted character and elsewhere served as powerful solvents of "iron triangles" and entrenched interests (Baumgartner and Jones, 1991; Kingdon, 1984; Sine and David, 2003). They also evoked antitrust measures against property insurers.

System failures repeatedly attracted hostile scrutiny and public interventions (see Table III). Monopoly rates and discrimination were driving forces for controversy. They led populists in Kansas, Texas, and other states to attack associations via anticompact measures from 1885 to 1910, and fueled an "era of legislative investigations" from 1909 to 1915, as nine states launched probes into insurance pricing (Brearley, 1916; Schneiberg and Soule, 2005). From 1921 to 1939, firms' efforts to subvert regulation prompted renewed public scrutiny in key states (Best's Fire and Casualty News, June, 1941:56; January, 1943:39-43; Crane, 1972; New York State, 1922). And in the 1940s, such efforts led the Justice Department to investigate the Southeastern Underwriters Association, subjecting insurance to the public spotlight nationwide and culminating in a 1944 Supreme Court ruling that insurance was subject to federal antitrust laws (Elmore, 1959).

The agent problem also attracted hostile scrutiny. As a reformer noted in the early 1900 s,

the public has always complained of the unreasonable expense ratio.... The high commission is in effect a corruption fund, producing favoritism, discrimination and an unwholesome greed for commissions, which blinds at least some agents to every consideration outside their commission.... [W] hen we multiply the agent's motive for gain and his utter irresponsibility ... by the number of poor agents of lax moral fibre throughout the land, it is easy to realize that the system of compensating agents leads not only to an inevitable increase in the expenses of the industry, but to a laxity ... on a scale so extensive as to produce ... criminal increase in fire waste (Wandel, 1935:190).

Indeed, such criticism surfaced in the trade press, legislative investigations, and insurance reports through the 1930s (e.g., see New York State, 1911; 1924:19-24, 1925:21, 1932:15-16; Western Underwriter, November 29, 1906:8). Rising expenses even led New York's commissioner to hold "acquisition cost conferences" that kept attention on commission costs (Bennett, 1954:53). Far from being taken for granted, associations and 
agents were repeatedly subject to controversy, public scrutiny, and hostile state interventions.

In sum, insurers were subject in this period to conditions for fundamental change that are highlighted both by rational-choice and organizational analysts. They faced not only material conditions for a shift to pricecompetitive markets and vertically integrated firms, namely, intermediate market failures and shifting prices in final markets, but also politico-cultural conditions, notably controversy, legitimacy crises, and antitrust policies.

\section{Institutional Outcomes}

Contrary to expectations, however, these conditions failed to produce such a transformation for eight decades. Exposure of the ways insurers and agents benefited at consumers' expense aroused the interest of insiders and regulators in reform. Yet both the industry and its critics defended the boundary between insurance and ordinary trades, meeting market failures, controversies, and trust-busting objections with incremental changes that extended, rather than replaced, the logic of associations (see Table III, right panel).

For the agent problem, actors opted repeatedly-and with little success-for commission compacts. As the Western Underwriter (January 29, 1903:7) urged, "What is needed is a straight company agreement to reduce expenses." Regulators also sought associational solutions such as acquisition-cost conferences and contingent contracts that tied commissions to losses (New York, 1924:19-24, 1925:21, 1932:15-16; Wandel, 1935:8687). So did companies, which formed commission-control bodies and "nocommission" compacts in the $1850 \mathrm{~s}, 5 \%$ or $10 \%$ compacts in the $1860 \mathrm{~s}$, $15 \%$ and $20 \%$ compacts in the 1880 s, and graded schemes of $10 / 15 / 25 \%$, $15 / 20 / 25 \%$, and more through the 1920s (Handy, 1916; Wandel, 1935).

Companies also extended the principle of association to the problem of monopoly, turning with success to prevention associations, collective bargaining, and pricing schemes (Brearley, 1916; Heimer, 1985; Schneiberg, 1999). In the 1890s, the National Board and local inspection bureaus began to survey conditions and fire-fighting facilities in cites and towns across the United States. After inspections, bureaus contacted local officials and groups, coupling rate hikes for documented problems with promises of rate cuts for reduced hazards. Bureaus also extended this logic to individuals via schedule rating, which defined a base rate for a property and a list of charges and credits for exposure, poor construction, and improvements that were found on inspection. Both reforms addressed the problem of monopoly cooperatively, using associations to link prices to hazards and to provide 
consumers with ways to lower rates by working within, rather than against, the existing system. Moreover, firms supported both reforms with prevention associations that brought firms, engineering societies, building trades, and consumers together to craft and disseminate building codes, standards, and prevention protocols.

Failure, controversy, and antitrust agitation fueled additional associational extensions through the 1940s. After investigations and anticompany politics, lawmakers opted to preserve the logic of association via regulated cooperation, enacting rate regulation in 33 states from 1911 to 1928 (Schneiberg and Bartley, 2001). After firms' manipulation of regulation sparked renewed scrutiny in the 1920s and 1930s, officials extended this logic again, expanding commissioners' powers and requiring firms to join data-pooling programs (Hobbs, 1942; New York State, 1922). After Justice Department hearings and a Supreme Court decision to apply federal antitrust law to insurance in the 1940s, officials opted again to extendand universalize-association (Meier, 1988; Rose, 1967). In 1945, Congress passed the McCarran-Ferguson Act, exempting insurance from federal antitrust law. In 1946 and 1947, nearly every state passed "All-Industry" laws that authorized and regulated association nationwide, reaffirming both the model of scientifically regulated cooperation and the line between insurance and ordinary trades.

In the end, failures, controversy, and legitimacy crises were critical for the shift to price-competitive markets and vertically integrated firms. But these conditions did not produce a new regime until they had (1) fostered defections and breaches that let peripheral players assert new analyses and claims in the sector, and (2) combined with a succession of models from a scientifically administered, quasi-public conception of insurance to a neo-classical, market-competition theory of insurance. Fundamental change rested on combinations, or a dynamic interplay between market failures, controversy, and the transposition of new models into the field. These combinations transformed preferences and the perceived benefits and costs of different systems, producing new coalitions and policies that redrew boundaries and admitted alternatives into the field. Table IV outlines the key events in this dynamic and their institutional outcomes.

\section{CONVERGENT FORCES AND FUNDAMENTAL CHANGE, 1940s-1970s}

The shift to direct writing and competitive markets flowed from interactions between failures, controversy, and new models of order- 


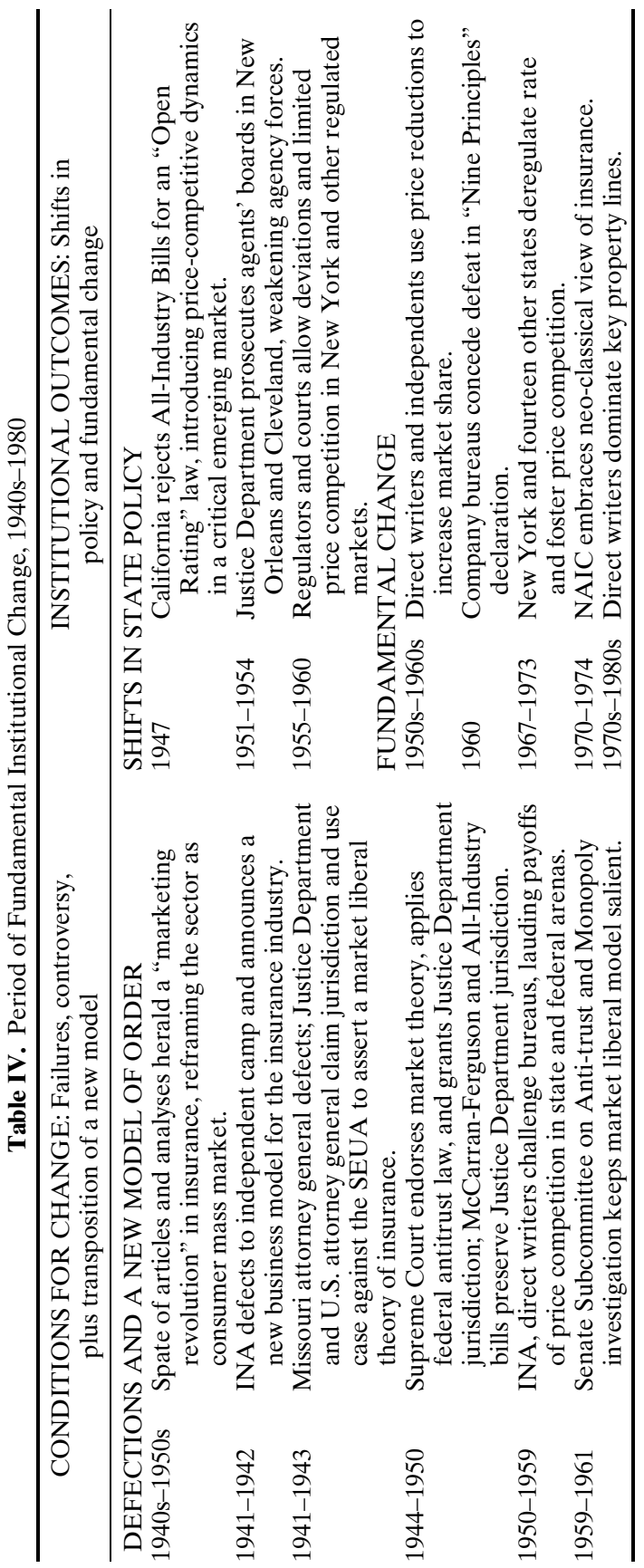


interactions in which key players defected from the system, breached boundaries, and let champions of alternatives reframe the existing regime.

\section{Failures, Defections, Transpositions}

One opportunity for a new model of insurance opened in the 1930s, as dissatisfaction over growing commissions led to acquisition-cost conferences. Conferences kept the commission problem salient for insiders and dramatized the failure of association in this area, providing challengers with grounds to intrude from the peripheries with new views and a case for alternatives (Bennett, 1955:53; New York, 1932:15-16; Wandel, 1935:30-32; 78-79). Indeed, rising commissions prompted a slew of new analyses, articles, and critiques in the 1940s and 1950s that framed the agency system as inappropriate for current business conditions (Best's Fire and Casualty News, February 1939:77, January 1942:42-43, August 1942:48; Kenney, 1959; Morrill, 1959). Fueled in part by direct writers, these attacks heralded a "marketing revolution" in insurance. They cast insurance as a mass consumer market, and highlighted how price competition, coupled with eliminating the middleman and his commissions, could mean huge savings for consumers. These analyses, in turn, blurred the lines between insurance and other industries, and held out to state policymakers the prospect of being able to deliver substantial benefits to their business and consumer constituencies.

Windows for a new frame also opened as INA, a leading agency company and association supporter, responded to rising costs with a similar analysis and a dramatic defection to the independent camp in the early 1940s (Rose, 1967:718-719; Whitney, 1958:360-361). The price-competitive logic and the payoffs to this defection were explicit. According to INA President John Diemand,

\footnotetext{
[the] policyholder's interests are being adversely affected ... by arbitrary rulings of company-controlled regulatory bodies and onerous state regulations.... [W]e have the added costs of doing business by virtue of excess commissions ... and little freedom in rate making and contractual dealing with individual risks.... [I]f there is sufficient redundancy in rates to warrant [high commissions], then such excess should be resolved through a reduction in the rate for the insurance desired. (Best's Fire and Casualty News, March 1942:29-32)
}

As INA's defection suggests, mounting costs and the prospect of eliminating "redundancy" were starting to get firms interested in pursuing a new way to increase their market share.

Several states also provided forums for reframing the system in the late 1930s and 1940s, holding proceedings that highlighted the failure of 
associations to failure control discrimination and high rates. ${ }^{7}$ But most significant was the move by Missouri officials to join forces with the Department of Justice, a forceful champion of a neo-classical model of pricecompetitive markets (Elmore, 1959; Hobbs, 1942:363-365; Rose, 1967). Driving this defection was the growing ability of firms to undermine regulation. In the 1930s, the Southeastern Underwriters Association used litigation and bribery to subvert rate-reduction orders and the Missouri superintendent of insurance, leading Missouri's attorney general to turn to federal authorities for help in 1941.

Emboldened by this defection and the evidence it supplied about prices, practices, and firms' "vast interstate schemes," the Justice Department and U.S. attorney general reassessed the principle that only the states had jurisdiction and laid claim to the sector. In February 1942, the attorney general concluded that the "the public interest [was] crying for protection and relief which could only be afforded under federal anti-trust law." In March, he convened a grand jury against the Southeastern Underwriters Association. In July, the Justice Department set loose its lawyers and neoclassically trained economists in a new public investigation.

This investigation unleashed a flood of new data, analysis, and critique. "[I]t is no secret," an observer noted, that firms' pricing practices led Justice Department economists to "view with suspicion claims as to scientific rating" and to conclude "that National Board statistics ... offer no true guide to the burning ratio of most classes of business" (Best's Fire and Casualty News, January 1943:39). In fact, the investigation produced evidence and arguments that insurers were engaged in a national conspiracy to defraud the public, that states lacked adequate safeguards, and that rates were so high that the losses insurers paid out in 1941 barely equaled one-third of the premiums collected (Crane, 1972:516-517; Elmore, 1959:10; Rose, 1967:693694).

These framing efforts swayed the grand jury, whose indictment led insurers toward a 1944 encounter with the Supreme Court. And while that encounter unfolded, direct writers joined another advocate of price-competitive markets-the Senate Subcommittee on Antitrust and Monopoly-to pressure states to reduce regulation (Hanson et al., 1974:4143; Rose, 1967). In its hearings, the subcommittee documented how firms manipulated regulation to raise rates and used this evidence to discredit the reigning conception of control.

\footnotetext{
${ }^{7}$ Hearings in Texas, California, and even New York disclosed how bureaus subverted scientific rate-making and public controls on rates and rate discrimination by reducing the risk classes for which they collected and provided loss data (Best's Fire and Casualty News, June 1941:56, January 1943:39-43.)
} 
The famous Merritt Committee report showed... defects of business which were current at that time. But its criticisms of destructive rate wars and ruinous competition... have little authority today in approaching the revolutionary marketing developments which have occurred in insurance.... Reliance upon the old Merritt committee findings suggests a rationalization to defend entrenched market positions.... [R] egulation of rates played into the hands of those groups of insurers who envisioned the possibility of maintaining ... control over rates by means of manipulating State administration. (U.S. Senate, 1961:5, 7)

These sentiments expressed an emerging neo-classical critique of regulation and kept that delegitimating vision salient among state officials at a critical juncture.

Together, such proceedings supplied actors on the margins with platforms for transposing a market competition model into the insurance field. Further, by bringing "new facts" to light, Justice probes and Congressional hearings dramatized that model's claims, discrediting theories of ruinous competition and scientific rates. Exploiting a material foundation of mounting failures, champions of the new model could credibly frame associations as the source of the sector's problems-as fraudulent conspiracies that fueled monopoly and exposed, rather than protected, the public to company greed. This model let challengers recast price competition as the solution to the sector's woes and as being in "the public interest," inverting the meanings of cooperation and competition, and assimilating insurance into the category of "ordinary trades."

\section{Realignments}

This reframing transformed state actors' perceptions of the costs of association and raised their awareness of the payoffs to alternatives, prompting new boundaries, coalitions, and policies. Justice Department efforts to recast associations as conspiracies against the public were telling: In 1944, the Supreme Court ruled in US v. Southeastern Underwriters Association that the Sherman Act and other federal antitrust acts applied to insurance. Ratifying the new view, the Court rejected theories of ruinous competition that had distinguished insurance from other trades and granted Justice and the FTC authority to intervene, altering jurisdictions and the balance of power in the industry (US v. SEUA, 322 U.S. 533; Elmore, 1959; Meier, 1988).

Predictably, firms and regulators fought this incursion and tried to restore boundaries, pressing Congress and the states to pass, respectively, the McCarran-Ferguson Act in 1945, and the All-Industry bills in 1946 and 1947 (Lilly, 1976; Rose, 1967). McCarran-Ferguson exempted property insurance from federal antitrust acts, provided that states would regulate the business. The All-Industry bills met that requirement via rate regulation. 
Yet, the deepening convergence of market failures and neo-classical models helped to crystallize a new coalition of federal authorities, state regulators, independents, and mutuals, one that left its marks on the new legislation (Crane, 1972; Meier, 1988). McCarran-Ferguson and the All-Industry Bills retained Sherman Act bans against boycotts, fixing a permanent role for federal antitrust agencies in insurance. Moreover, the All-Industry bills both expanded regulators' power over rating bureaus and required bureaus to provide mutuals with full services and membership, ending decades of exclusion (Hanson et al., 1974; Kimball and Boyce, 1958).

Further, the convergence of models and market failures created a context for three policy shifts. Encouraged by independents, California rejected the All-Industry bills for its 1947 "open rating" law (Weinstock and Maloney, 1971:67). This law fostered price competition in what was becoming the nation's largest insurance market, creating a laboratory that yielded potent precedents for critics of association.

Second, the Justice Department sued to bar private enforcement by local boards of agents, winning cases against boards in Cleveland and New Orleans in 1951 and 1954 (Bennett, 1954; Whitney, 1958). These attacks weakened agents - the linchpin of association and archenemy of direct writing - forcing them to abandon their role in enforcing compacts, and leaving associations completely dependent on the states to enforce rates.

Third, under pressure from independents, direct writers, and federal officials, core states began to allow price competition in the 1950s. In fact, by relentlessly reframing associations as the source of the sector's problems, and price competition as the solution, Justice probes, defections, and Congressional hearings changed policy environments, providing state officials with interests in new policies. They put regulators on the spot, casting support for association as support for vested interests bent on exploiting the public, discrediting concerns over ruinous competition, and highlighting the politically attractive option of using competition to deliver reduced rates to constituencies. In response, officials in New York, Washington, Illinois, and Virginia began to lift barriers to independent pricing, granting direct writers and independents the right to deviate from bureau rates (Meier, 1988; Moser, 1950; Whitney, 1958). ${ }^{8}$

\footnotetext{
${ }^{8}$ Until the mid-1950s, associations blocked competition by entering the rate-approval process as "aggrieved parties" to challenge deviations, by demanding onerous filings to support a deviation, and by suing in court to void deviations (U.S. Senate, 1961). But in light of arguments for competition, and in proceedings initiated by direct writers and independents like INA, Allstate, and Liberty Mutual, state officials began to end these practices. Courts and regulators approved a handful of applications for percentage deviations below bureau rates, reduced filing requirements, and eliminated aggrieved-party status for associations. Regulators then let firms subscribe to bureau services for some risks, while independently making or filing rates for others.
} 


\section{New Logics and Rapid Change}

These policies inadvertently unleashed a dynamic that settled the conflict between two incompatible institutional logics (U.S. Department of Justice, 1977:29-30). On the one hand, direct writers like Allstate required unregulated markets and the freedom to reduce prices in order to survive and prosper. Absent this capacity, they could neither translate their expropriation of the middleman into competitive advantage nor exploit the principal benefit of vertical integration-gaining market share by cutting commission costs and premiums. Direct writers' existence hinged on breaking bureau control over prices.

On the other hand, associations needed effective price controls. Absent the ability to stop price-cutting, associations could not protect members from being "suckered" by free riders who cheated on rate agreements. Cheaters took business from bureau members, so firms who continued to comply with bureau rates found themselves handicapped in the competitive struggle. Even limited price-cutting could force loyalists to defect and even to oppose the system, eventually snowballing into a wholesale collapse. Accordingly, company bureaus and agent associations formed a coalition that fought direct writers viciously.

Acts by regulators in the 1950s to allow limited independent pricing thus dealt bureaus a decisive defeat. Turning reduced commissions and losses into price cuts of $10-40 \%$, direct writers fueled price competition and dominated homeowners and automobile insurance (Etgar, 1976; Joskow, 1973:405; Lusk and Hibbard, 1981; Meier, 1988:9-10). ${ }^{9}$ Agents and bureaus resisted, as did insurance commissioners. But the intrusion of the new logic so rapidly changed dynamics in insurance markets-and so profoundly handicapped bureau loyalists-that bureaus conceded defeat in a "nine principles" endorsement of competition in 1960 (Crane, 1962:71-73).

In fact, the payoffs of this shift for consumers and regulators yielded new precedents and analyses, accelerating the succession from the old conception of insurance to a neo-classical view. From 1967 to 1973, 16 states, including New York embraced the new logic and used its successes to justify deregulation.

Those who do not wish to compete in price have conjured many possible evils of open competition.... During the past 50 years, there has been no evidence in

\footnotetext{
${ }^{9}$ Direct writers enjoyed an advantage of at least 10-12 percentage points over agency companies in commissions, paying rates as low as $10 \%$ (see also Cummins and VanDerhei, 1979). Not surprisingly, this put great pressure on agents and agency companies to cut commissions, and by the late 1950 s, those rates dropped $50 \%$ from their $30 \%$ plus levels in the 1930s and 1940s to roughly $20 \%$ in 1958 (Hensley, 1962:185). Also not surprisingly, INA lead this charge, cutting its commission rates from $30 \%$ to $15-20 \%$ in California in 1954 (Whitney, 1958:373).
} 
California [or any] other jurisdiction that rate competition leads to destructive rate wars. Their memory haunted the Merritt Committee a half-century ago, but our own experience and the findings of the most recent Congressional study should lay the spectre to rest. (New York, 1969:17-18)

Even the National Association of Insurance Commissioners eventually conceded to the force of these precedents, assimilating insurance within a neo-classical paradigm of market competition in their influential 1974 report, tellingly titled, Monitoring Competition: A Means of Regulating the Property and Liability Insurance Business. By this point, eliding the lines between property insurance and ordinary trades was a forgone conclusion.

\section{EXPLAINING INSTITUTIONAL CHANGE: DISCUSSION AND EXTENSIONS}

Rational-choice and organizational institutionalists have made substantial progress in specifying when and how institutions change (Clemens, 1997; Edelman, 1990; Fligstein, 1990; Knight, 2001; Meyer et al., 1997; Ostrom, 1990; Williamson, 1985). Yet, as the foregoing reveals, existing research is plagued by substantial indeterminacy regarding the source of the pressures or conditions for change and the type of change that will result. First, scholars in both camps typically look beyond existing institutions to external shocks or extra-institutional factors as the source or initial impetus for change, giving pride of place to new technology, demography, or other exogenous jolts. They have done but little work on how established institutions endogenously generate pressures or conditions for transformation.

Second, neither approach adequately specifies the conditions for fundamental versus incremental change. Market failures or price shocks will induce problem solving, but they do not uniquely determine outcomes (Burk, 1988). Indeed, multiple equilibria are possible for any set of problems, including more or less efficient new solutions, the abandonment of old practices, or stagnation (Dobbin, 1994; Greve, 1995; Peltzman, 1989). Moreover, because actors are embedded in institutions, failures and shifting prices are likely to evoke incremental efforts, begging questions about when fundamental change occurs.

Similarly, controversies and alternative logics may be vital for fundamental change, as are state policies that disrupt or redefine field boundaries or the range of acceptable forms (Campbell and Lindberg, 1990; Dobbin and Dowd, 2000; Schneiberg, 1999; Stryker, 2000). Yet, alternatives and their champions are often, if not always, present on the margins, and can persist there without effect (Greenwood and Hinings, 1996; Kingdon, 1984). Further, while scandal and scrutiny fuel change, they can also 
evoke politics and policies that defend and elaborate existing systems and boundaries (Abolafia, 1996). Here, too, key factors do not themselves yield or uniquely determine change. When do challengers or competing logics become credible? When do states react to existing institutions losing their taken for granted character by endorsing new models instead of enforcing existing logics and boundaries? When do alternative models attract new, winning coalitions, rather than strengthen existing forces or fuel efforts to prevent breaches? Some find that performance crises and challengers' abilities to link problems to new models raise the odds of fundamental change (Heimer, 1999; Oliver, 1992; Sine and David, 2003). But this work has not yet specified when crises emerge, how they render critiques or alternatives credible, or how they combine with cultural and political forces to produce such change.

My analysis of the insurance industry reduces these indeterminacies in two ways. It looks beyond external shocks to develop data on how institutions endogenously generate conditions for change. And it compares two distinct periods and patterns of change, providing data for new hypotheses about the conditions for fundamental as opposed to incremental transformation.

\section{Endogenous Change}

As DiMaggio $(1988,1991)$ has pointed out, institutionalization is a potentially contradictory, self-negating process: It can produce new actors or strategies whose interests or realization subvert the system on which the efficacy of those actors and strategies rests. However, barely a handful of analysts have capitalized on this insight. One possibility is to draw on Friedland and Alford's (1991) arguments about the ubiquity of multiple logics within fields. As organizations seek legitimacy by adopting sanctioned practices or forms, they invariably generate unintended delegitimation, fueling intra- and inter-organizational conflict (D'Aunno et al., 1991; Stryker, 2000; Suchman, 1995). Multiple logics can also inadvertently fuel feedback. As Edelman shows (2005; see also Edelman et al., 1999), subjecting organizations to legal logics evoked compliance strategies based on managerial logics of efficiency, which subsequently altered legal reasoning as judges invoked and incorporated those strategies in their rulings.

The insurance case reveals different mechanisms, identified in part by suggestions that institutionalization produces exhaustion, resource scarcities, accumulating costs, and conflicts of interest that can undermine systems from within (Greif, 1998; Leblebici et al., 1991; North and Weingast, 1989; Peltzman, 1989). First, institutionalization creates its own opponents. As champions of a model achieve dominance within a field, they create 
losers and new grievances, pushing other players and logics to the peripheries, where they may appropriate new ideas or forms, combine or transpose logics from other fields, and persist as resources or coalition partners for future challenges (Clemens, 1997; Leblebici et al., 1991; Morrill, 2005).

Second, institutions embody problem-solving trade-offs and can produce new failures and price shifts that accumulate over time. Actors craft institutions to solve particular coordination problems, including the erosion of collective goods, costs of contracting under incomplete information, and problems of learning (Alchian and Demsetz, 1972; Ostrom, 1990; Powell et al., 1996). But institution-building is boundedly rational. While actors sometimes hedge their bets via multiple or hybrid solutions, they typically build systems around a central problem, a specific vision of the setting and its challenges, a limited set of routines, and a single model of rationality or efficiency (Fligstein, 1990; Meyer et al., 1997). Once in place, institutions crafted to solve one set of problems are often ill-suited or only imperfectly adaptable for managing others (Hollingsworth and Streeck, 1994).

Moreover, institutional solutions can create new relationships, interests, and capacities for learning and strategic behavior, empowering new actors and channeling competition and resource use in dysfunctional ways (Noll and Owen, 1983; Vietor, 1994). For example, U.S. mass producers used the vertically integrated corporation to solve exchange problems they faced with suppliers and distributors (Chandler, 1977; Williamson, 1975). This solution stabilized demand and secured high-volume flows of raw materials and finished goods. But it also bureaucratized firms and divided industry into self-sufficient units, creating problems of rigidity, learning, and collective action (Kenworthy, 1995; Streeck, 1991). Or, as the insurance case shows, using associations to solve problems of competition and produce collective goods can foster new transactional problems, nonprice rivalries, bottlenecks, and hold-ups, granting distributors veto power and increasing capacities for predatory behavior. In short, institutions designed to solve one set of problems can induce conventional practices and relationships that subsequently fuel new problems and failures, new resource scarcities (Leblebici et al., 1991), and "cycles of opportunism" (Abolafia, 1996), thereby increasing the payoffs for fundamental change.

Nor are endogenous conditions for change always purely material. Accumulating failures and price shifts can foster new organizational forms to exploit new opportunities (Ingram, 1998), creating vehicles by which upstarts can challenge incumbents and introduce new logics into fields (Clemens, 1997; Schneiberg, 2002). They can also create controversy, public criticism, and legitimacy crises that subvert the taken for granted character of established systems (Stryker, 2000). Controversy can emerge as actors affected by growing costs organize to subject a system to scrutiny 
and debate, or political entrepreneurs may use hearings or investigations to craft new coalitions (Wilson, 1980). Yet, once produced, scrutiny and scandal have great disruptive potential. Not only do they increase the salience of system failures, but they also create forums for promulgating critiques and exposing the partisan character of systems that policymakers and their publics had previously viewed as rational, efficient solutions (Baumgartner and Jones, 1991; Kingdon, 1984; Sine and David, 2003). In short, institutions can internally generate material and symbolic conditions for fundamental transformation.

\section{Incremental and Fundamental Change}

But as the foregoing also makes clear, market failure and controversy will not themselves yield fundamental change. Multiple paths are possible. And as long as dominant models continue to frame problem solving and debates, states and other players will defend existing boundaries, reproducing existing schemes even as public investigations expose their failings to scrutiny (Clemens and Cook, 1999; Hoffman and Ventresca, 1999). As documented above, the weight of existing institutions make incremental rather than fundamental change the most likely result of failure or controversy. Institutions create sunk costs and vested interests (North, 1990; Vietor, 1994), veto points for those threatened by new solutions (Immergut, 1992), and mechanisms for shifting the costs of failures onto unorganized groups (Wilson, 1980). They also enact theories or cognitive schemes that can obscure the significance of problems, render alternatives irrational, and bound rationality within extant problem-solving routines (DiMaggio and Powell, 1983; Dobbin, 1994; Oliver, 1992). In insurance, theories of ruinous competition and the specters of conflagration and mass bankruptcy cast price warfare as the central problem, overshadowing for firms, regulators, and consumer groups the costs of monopoly and high commissions.

On the basis of my case study, I argue that fundamental change rests on a convergence between: (1) shifting prices, market failures, and controversies that problematize existing systems, and (2) efforts by challengers to craft or transpose new models of order and forms into the field. In these efforts, champions of new models and forms seek to convince core players that alternatives are efficient, rational, or in the public interest. When successful, they recast existing institutions as inherently irrational and flawed. They invert traditional meanings and alter key players' perceptions of the costs and benefits of competing systems, prompting politics and polices that redraw boundaries and admit new players and forms into the field. Absent this transposition or succession of models, states and other actors will continue to define the setting and its problems in ways that demand old 
solutions. They will calculate that the costs of collective action exceed the payoffs to change, cast alternatives as dangerous, defend existing boundaries, and meet problems or controversy by extending existing institutions.

Vital here is a dynamic feedback among factors stressed by different strands of new institutionalism-shifting prices or failures, controversies, and efforts by challengers on the peripheries to advance new models and forms. Change and innovation often begin at the margins, where actors are exposed to multiple fields, relatively free from social control, and well placed to borrow models or combine principles into novel approaches (Leblebici et al., 1991; Morrill, 2005; Palmer and Barber, 2001; Schneiberg and Clemens, 2005; Stearns and Allan, 1996). Yet alternatives and their champions can persist on the peripheries without effect, only becoming active or efficacious when failures develop and are broadly recognized.

Accumulating failures can fuel the transposition of models and forms in various ways. First, mounting problems generate opportunities and interests for entrepreneurs or advocates of new logics to promote their claims, inducing organization and theorization on the margins of fields. For example, where federal antitrust agencies regularly intervened in the economy in the twentieth century, they did not develop an interest in insurance until company predation and the growing costs of association convinced them that they could make a case for overturning decades of case law and redrawing long-standing boundaries.

In addition, accumulating problems lend force to critiques and new models, increasing the credibility of challengers' claims that they can solve key problems and deliver gains to members in a field. Unsolved problems are akin to anomalies that render systems vulnerable to attack (Babb, 1996; Ellingson, 1995) and support arguments for alternatives. They give weight to challengers' contentions in public debate, providing a material foundation for them to highlight new theories, engage in claims-making and bids for authority, and call existing distinctions into question (Fligstein, 1990; Heimer, 1999; Oliver, 1992).

Problems and price shifts may also lead insiders-states, foundations, professions - to commission studies or hold hearings to search for solutions and to hedge their bets by supporting experiments or fringe elements (Campbell, 2004; Leblebici et al., 1991). Mounting failures can even induce insiders who suffer most from problems or are most able to exploit a new regime to defect to the periphery and espouse alternative logics or forms. In insurance, high rates gave bureau loyalists like INA interests in joining independents and pursuing price competition, and the ability of bureaus to subvert regulation gave state officials interests in bringing federal agencies into the field. In short, accumulating failures and price shifts can foster 
dissatisfaction and discussion, giving advocates of alternatives credibility, forums, and political support for breaching boundaries and advancing new analyses and forms.

In turn, new analyses and the growing salience of new models and forms let challengers amplify problems and shifts in relative prices. With credibility and access to media, hearings, or the academy, challengers can use new models to highlight and recast problems, to reframe extant systems as inherently irrational or as the sources of existing problems, and to discredit their underlying theories as outdated or as the rationalizations of vested interests.

Challengers can also use new theories of order to justify alternative forms and make their availability and suitability more broadly known among policymakers and their constituencies, either by sharpening or blurring distinctions between fields or establishing correspondences, analogies, and identities across problems or solutions in different settings. Theorization of this sort is a key mechanism for diffusing critiques, new practices, and new organizational forms (Strang and Meyer, 1994; Strang and Soule, 1998). Indeed, increasing the awareness of competing logics and articulating alternative solutions to unsolved problems in public forums are powerful tools for deepening controversy and undermining the legitimacy of existing institutions (Greenwood and Hinings, 1996; Lounsbury et al., 2003; Sine and David, 2003; Stryker, 2000).

Above all, by elaborating new models and analyses, challengers can highlight the payoffs of new schemes for various groups, link proposals for alternatives to expert judgment, and shape public opinion, altering policymakers' perceptions of the costs and benefits of competing logics. New theories are material forces (Campbell, 2001; Strang and Meyer, 1994). They provide challengers with rhetorical resources (Dobbin, 1994) or frames (Snow and Benford, 1988; Tarrow, 1994) for emphasizing payoffs and price shifts, fostering doubt about the rationality of existing institutions, and linking new forms to the public good (Ingram, 1998). New models thus reduce the costs of organizing collectively for change and increase incentives for states and other actors to align themselves with challengers and alternatives.

In insurance, using new models to alter key players' perceptions and preferences was decisive for fundamental change. It was the Justice Department's use of the market competition model to assimilate insurance into the category of "ordinary trades," recast association as the source of the industry's problems, and redefine the "public interest" that led the Supreme Court to reverse itself, alter long-standing boundaries, and admit champions of price competition into the field. Moreover, by persistently reframing the established system, INA defections, Justice Department investigations, and Congressional hearings transformed state officials' perceptions of the 
costs and benefits of cooperation or price competition, creating interests among those officials in reversing policies that insulated the insurance sector from market forces.

Chances of fundamental change increase substantially as interactions between models and market failures broaden core-periphery coalitions and evoke actions by states that admit new forms into a field. Given the central role of states in fixing boundaries, policies that tolerate breaches or new logics or forms can dramatically accelerate change (Abolafia, 1996). Such policies may be narrow in scope, authorizing limited experiments or grafting bits of new forms onto old (Haveman and Rao, 1997; Sabel and Zeitlin, 1997). Yet giving even limited status to new models or forms can yield normative fragmentation and political realignments that destabilize the existing system (Ingram, 1998; Oliver, 1992). Once admitted, new logics and forms can complete the erosion of legitimacy (D'Aunno et al., 1991; Stryker, 2000). They can fuel behavioral or competitive dynamics that raise the enforcement costs of old controls. They can engender interests and coalitions at odds with the old regime. And by delivering material payoffs, new forms can dramatize their own theories of order, legitimating new boundaries and confirming analyses that discredit old systems as inefficient or unjust.

\section{Generality}

Space precludes a full assessment, but prior research suggests that both arguments apply beyond insurance to other cases where change has occurred in the context of existing institutions, notably the "deregulation" of U.S. industries in the 1970s and 1980s. First, existing institutions generated conditions for change, as systems built to foster market stability and infrastructure development created new interests and problems (Noll and Owen, 1983). In the airline industry, controls on prices, routes, and entry induced service rivalries where carriers increased flights at desirable times, provided nonstop service, upgraded facilities, and expanded capacity to make seats available on short notice (Jordan, 1970; McCraw, 1984; Peltzman, 1989; Vietor, 1994). Service rivalry helped promote jet service, but it also sparked capacity and "lounge wars" that put piano bars in first class and left flights less than half full by 1971 . Such strategies saddled airlines with mounting costs, evoking fare investigations, defections from the regulatory coalition, and challenges by upstart carriers.

Endogenous forces also drove change in telecommunications, where commitments to universal service and efforts to allocate costs rationally fueled cross-subsidization (Joskow and Rose, 1989; Noll, 1985; Posner, 1971). Regulating AT \& T created a dilemma of distributing expenses ("separating the ratebase") across services in a network whose elements were 
inseparable. Regulators met this problem via principles of proportionality and equality. They used "rate-averaging" to charge equal prices for equal distances and separation based on "actual use" to allocate local exchange costs to interstate service in proportion to long-distance use. Yet these solutions raised long-distance rates to subsidize local service, shifting costs from residential customers to business consumers of long distance, and from urban to rural areas whose costs of connection were high. Over time, these "distortions" grew as new technologies cut long-distance costs relative to local phone lines, inducing defections by business customers, challenges from upstarts like MCI, and public criticism.

Natural gas institutions also endogenously produced failure: Rate controls and "split the difference" distributional struggles over prices induced shortages in natural gas and overinvestment in costly alternatives (see especially Vietor, 1994). A key dilemma was the problem of setting prices high enough to encourage exploration for new gas, yet low enough to avoid windfall profits for old gas that would benefit producers at consumers' expense. Regulators addressed this dilemma using a two-tier pricing system that notched prices toward a point midway between the lowest prices urged by consumers and the incentive rates urged by producers. This settlement stimulated demand, but discouraged exploration, creating a shortage of natural gas. When coupled with cost-plus regulation, shortages led distributors to pursue capital-intensive, high-cost substitutes for natural gas, yielding overinvestment in those sources, mounting costs, shortages of cheap gas, and pressure on the Carter administration for deregulation.

Second, failures did not produce fundamental change until they combined with efforts by champions of new models of markets to define alternatives as efficient or rational. In the end, deregulation rested on economists like George Stigler, William Jordan, and Alfred Kahn, who used neoclassical analyses to recast regulation as the creator of monopoly, lawmakers as sellers of public power for private ends, and competition as in consumers' interest (Derthick and Quirk, 1985; McCraw, 1984; Vietor, 1994). As policy-entrepreneurs, economists used material failures to forge ties with consumer advocates like Ed Kennedy and to gain access to hearings, policy debates, committees, and posts. Once there, economistentrepreneurs worked to discredit theories of regulation and transform perceptions among policymakers and the press of the costs of regulation and competition. Where economists could credibly link sector problems with a neo-classical analysis to make a coherent case for the payoffs to competition, as in airlines and telecommunications, deregulatory coalitions emerged and won, policymakers redrew boundaries to admit challengers, and fundamental change occurred. But where this convergence did not develop, as in natural gas, where economists could not make a simple and direct case for the payoffs to consumers of deregulation, what emerged 
instead were incremental reforms and failures to forge bipartisan coalitions for wholesale change.

These considerations suggest that my arguments about both the endogenous sources and combinations of conditions needed for fundamental change can be fruitfully carried beyond the insurance case. They also suggest directions for future research. Studies of incremental and fundamental change across private institutions, or institutions built for different problems, would clarify scope conditions and elaborate key claims. ${ }^{10}$ So would studies of simultaneous transformation in multiple sectors, as in deregulation, which raises questions about when champions of alternatives can transpose models across sectors, use failures or successes in one setting to gain hearings in another, and forge cross-field coalitions for change.

To be sure, the foregoing arguments are less likely to apply to the creation of new fields, as in the rise of consumer protection (Rao, 1998) or French cuisine (Ferguson, 1998), where institutions were absent or in formation. Nor would they directly apply where institutions are poorly articulated, where fields have not crystallized around a single logic, or where competing, equally powerful models prevail (D'Aunno et al., 1991). Building or consolidating systems in "greenfield" settings may rest on extending existing models from other fields (Clemens, 1997; Dobbin, 1994). It may also hinge on combining models with market failure. ${ }^{11}$ Yet, absent welldeveloped systems, endogenous dynamics will not be a significant source of pressures for action. Moreover, with the parameters of action less fixed at the outset by local systems, vested interests, or established routines, introducing qualitatively new logics may rest less heavily, if at all, on explosive combinations of institutional processes.

\section{CONCLUSION}

Institutions, paraphrasing Marx, can be their own gravediggers. Moreover, explaining which particular path change takes means abandoning reductionism in favor of combining various strands of new institutional theory.

The payoff to thinking endogenously and to integrating rational choice and organizational institutionalisms is considerable (Campbell and

${ }^{10}$ In fact, studies of the early radio (Leblebici et al., 1991) and financial services industries (Abolafia, 1996; Stearns and Allen, 1996) suggest that private institutions also internally generate conditions for change, and that fundamental change there likewise rested on the linking of new models and forms to existing material problems by outsiders.

${ }^{11}$ This was true in early fire insurance, where linking market failures to a model of insurance as a quasi-public market crystallized a winning coalition in support of association (Schneiberg, 1999), and in the consumer watchdog field, where combining a vision of impartial, scientific, and apolitical testing with market failures in consumer goods sectors helped settle conflicts between competing models of consumer advocacy (Rao, 1998). 
Pederson, 2001; Hall, 1992; Heimer, 1999). First, it reduces indeterminacies in prior theory. By highlighting coordination problems, material foundations, and the rational-adaptive side of institutional change, we can help to explain when and why challenges from the periphery, controversy, new models of order, and the politico-cultural factors stressed by organizational analysts have the greatest impact. And by highlighting controversy, challenges from the periphery, and model transposition, we can explain how market failures and "efficient" solutions are redefined, how fundamental change becomes valued, and how boundedly rational actors figure out exactly what is in their material interests.

This approach also sheds new light on politics and policies of change, contributing to political analyses of institutions (Abolafia, 1996; Fligstein, 1996; Mizruchi and Fein, 1999; Perrow, 2002; Roy, 1997). Thinking endogenously or combining institutionalisms is not to deny power and politics: The analysis here confirms the centrality of coalition-building, balances of power, and state policy in fostering or preventing fundamental change. Rather the point is to identify how power, politics, and polices are, at least in part, institutionally determined-how they have their own institutional roots, endogenous sources or triggers, and their own simultaneously material and symbolic foundations (Bartley and Schneiberg, 2002; Thornton, 2002).

Finally, thinking endogenously and integrating approaches invites new conceptions of the trajectories of change. Prior work on path dependence and institutions as bases of order yields important insight into the sequences underlying punctuated equilibria and fundamental change. Fundamental change often unfolds through exogenous shock, crisis, and deinstitutionalization, followed by settlements, diffusion, and the rise of a new system. But the foregoing analysis reveals other paths to punctuated equilibria: Punctuation and fundamental change can also begin endogenously and develop as a sequence of internally produced failures, accumulating costs and controversy, followed by incremental reform, transposition of new forms and models, and the onset of an explosive and dynamic combination of conditions for change.

\section{ACKNOWLEDGMENTS}

I thank Lis Clemens, Mark Chaves, Frank Dobbin, Cal Morrill, Chick Perrow, Sun-Ki Chai, Kathleen Schwartzman, Marc Ventresca, Huggy Rao, the members of the Social Organizational Seminar at the University of Arizona, and the participants at the Workshop on Institutional Conflict and Change at Northwestern University for their thoughtful comments on drafts of this paper. The usual caveats apply. 


\section{REFERENCES}

\begin{abstract}
Abolafia, Mitchel
1996 Making Markets: Opportunism and Restraint on Wall Street. Cambridge, MA: Harvard University Press.

Akerloff, George A

1970 "The market for lemons: Quality uncertainty and the market mechanism." Quarterly Journal of Economics 84:485-500.
\end{abstract}

Alchian, Armen, and Harold Demsetz

1972 "Production, information costs and economic organization." American Economic Review 62:777-795.

Alchian, Armen, and Susan Woodward

1988 "The firm is dead: Long live the firm." Journal of Economic Literature 26:65-79.

Anderson, Erin

1985 "The salesperson as outside agent or employee: A transaction cost analysis." Marketing Science 4:234-254.

Anderson, Erin, and David Schmittlein

1984 "Integration of the sales force: An empirical examination." Rand Journal of Economics 15:385-395.

Arrow, Kenneth

1963 "Uncertainty and the welfare economics of medical care." In Essays in the Theory of Risk Bearing: 117-219. Chicago: Markham, 1971.

Babb, Sarah

1996 "'A true American system of finance”: Frame resonance in the U.S. labor movement, 1866 to 1886 ." American Sociological Review 61:1033-1052.

\section{Barley, Stephen}

1986 "Technology as an occasion for structuring: Evidence from observations of CT scanners and the social order of radiology departments." Administrative Science Quarterly 31:78-108.

Bartley, Tim, and Marc Schneiberg

2002 "Rationality and institutional contingency: The varying politics of economic regulation in the fire insurance industry." Sociological Perspectives 45:47-79.

Bates, Robert

1998 "The International Coffee Organization: An international institution." In R. Bates, A. Greif, M. Levi, J. L. Rosenthal, and B. Weingast (eds.), Analytical Narratives: 194-230.
Princeton, NJ: Princeton University Press.

Baumgartner, Frank, and Bryan Jones

1991 "Agenda dynamics and policy subsystems." Journal of Politics 4:1044-1074.

\section{Bennett, Walter}

1955 History of the National Association of Insurance Agents. Cincinnati: National Underwriter.

\section{Best, A. M.}

Various years Best's Fire and Casualty Insurance News. New York: Alfred M. Best

\section{Bowman, John R.}

1989 Capitalist Collective Action. Cambridge, UK: Cambridge University Press.

\section{Brearley, Harry}

1916 The History of the National Board of Fire Underwriters. New York: Frederick Stokes.

Burk, James

1988 Values in the Marketplace. Berlin: Walter de Gruyter.

\section{Campbell, John}

2001 "Institutional analysis and the role of ideas in political economy." In John Campbell and Ove Pederson (eds.), The Rise of Neoliberalism and Institutional Analysis: 159-189. Princeton, NJ: Princeton University Press.

2004 Institutional Change and Globalization. Princeton, NJ: Princeton University Press.

Campbell, John, J. Rogers Hollingsworth, and Leon Lindberg

1991 Governance of the American Economy. Cambridge, UK: Cambridge University Press.

Campbell, John, and Leon Lindberg

1990 "Property rights and the organization of economic activity by the state." American Sociological Review 5:634647.

Campbell, John, and Ove Pederson

2001 "Conclusion: The second movement in institutional analysis." In John Campbell and Ove Pederson (eds.), The Rise of Neoliberalism and Institutional Analysis: 249-282. Princeton, NJ: Princeton University Press.

Chandler, Alfred D., Jr.

1977 The Visible Hand. Cambridge, MA: Harvard University Press 
Clemens, Elisabeth

1997 The People's Lobby: Organizational Innovation and the Rise of Interest Group Politics in the United States. Chicago: University of Chicago Press.

Clemens, Elisabeth, and James Cook

1999 "Politics and institutionalism: Explaining durability and change." Annual Review of Sociology 25:441466.

Crane, Frederick

1962 Automobile Insurance Rate Regulation: The Public Control of Price Competition. Columbus, OH: Ohio State University.

1972 "Rate regulation: The reason why." Journal of Risk and Insurance 39:511534.

Crouch, Colin, and Henry Farrell

2004 "Breaking the path of institutional development? Alternatives to the new determinism." Rationality and Society. 16:5-43.

Cummins, J. David, and Jack VanDerhei

1979 A note on the relative efficiency of property liability insurance distribution systems. Bell Journal of Economics 10:709-719.

D'Aunno, Thomas, Robert Sutton, and Richard Price

1991 "Isomorphism and external support in conflicting institutional environments: A study of drug abuse treatment units." Academy of Management Journal 3:636-661.

Davis, Gerald, Kristina Diekmann, and Catherine Tinsley

1994 "The deinstitutionalization of conglomerate rirms in the 1980s." American Sociological Review 59:547-570.

Davis, Gerald, and Henrich Greve

1997 "Corporate elite networks and governance change in the 1980s." American Journal of Sociology, 103:1-37

Dean, A. F.

1901 The Rationale of Fire Rates. Chicago: J. M. Murphy.

Derthick, Martha, and Paul Quirk

1985 Politics of Deregulation. Washington, DC: The Brookings Institution.

DiMaggio, Paul

1988 "Interest and agency in institutional theory." In Lynne Zucker (ed.), Institutional Patterns and Organiza- tions: Culture and Environment: 3-22. Cambridge, MA: Ballinger.

1991 "Constructing an organizational field as a professional Project: U.S. art museums, 1920-1940.” In P. DiMaggio and W. Powell (eds.), The New Institutionalism in Organizational Analysis: 267-292. Chicago: University of Chicago Press.

DiMaggio, Paul, and Walter Powell

1983 "The iron cage revisited: Institutional isomorphism and collective rationality in organizational fields." American Sociological Review 48:4769.

Djelic, Marie-Laure

1998 Exporting the American Model: The Postwar Transformation of European Business. New York: Oxford University Press

Dobbin, Frank

1994 Forging Industrial Policy. New York: Cambridge University Press.

Dobbin Frank, and Timothy Dowd

2000 "The market that anti-trust built." American Sociological Review 65:631-657.

\section{Edelman, Lauren}

1990 "Legal environments and organizational governance: The expansion of due process in the American workplace." American Journal of Sociology 95:1401-1440.

2005 "Overlapping fields and constructed legalities: The endogeneity of law." In W. W. Powell and D. Jones (eds.), How Institutions Change. Chicago: University of Chicago Press.

Edelman, Lauren, Sally Riggs Fuller, and Iona Mara-Drita

2001 "Diversity rhetoric and the managerialization of law." American Journal of Sociology 106:15891641.

Edelman, Lauren, Christopher Uggen, and Howard Erlanger

1999 "The endogeneity of legal regulation: Grievance procedures as rational myth." American Journal of Sociology, 105:406-454.

Ellingson, Stephen

1995 "The dialectic of discourse and collective action." American Journal of Sociology 1:100-144. 


\section{Elmore, Franklin.}

1959 "How insurance became commerce." In H. Wayne Snider (ed.), Readings in Property Casualty Insurance: 497-522. Homewood, IL: Richard D. Irwin.

\section{Etgar, Michael}

1976 "Service performance of insurance distributors." Journal of Risk and Insurance 43: 487-499.

\section{Ferguson, Priscilla}

1998 "A cultural field in the making: Gastronomy in 19th-century France." American Journal of Sociology 104:597-641.

Fligstein, Neil

1990 The Transformation of Corporate Control. Cambridge, MA: Harvard University.

1996 "A political-cultural approach to market institutions." American Sociological Review 4:656-673.

Frech, H. E., and Joseph Samprone

1980 "The welfare loss of excess nonprice competition: The case of propertyliability insurance regulation." Journal of Law and Economics 23:429-440.

Freeland, Robert

2000 "Creating holdup through vertical integration." Journal of Law and Economics 42:33-66.

\section{Friedland, Roger, and Robert Alford}

1991 "Bringing society back in: Symbols, practices and institutional contradictions." In P. DiMaggio and W. Powell (eds.), The New Institutionalism in Organizational Analysis: 232-263. Chicago: University of Chicago Press.

\section{Greenwood, Royston, and C. R. Hinings}

1996 "Understanding radical organizational change: Bringing together the old and new institutionalism." Academy of Management Review 4:1022-1054.

\section{Greif, Avner}

1998 "Self-enforcing political systems and economic growth: Late medieval Genoa." In R. Bates, A. Greif, M. Levi, J. L. Rosenthal, and B. Weingast (eds.), Analytical Narratives: 23-63. Princeton, NJ: Princeton University Press.

\section{Greve, Henrich}

1995 "Jumping ship: The diffusion of strategy abandonment." Administrative Science Quarterly 40:444-473.

\section{Grossman, Sanford, and Oliver Hart}

1986 "The costs and benefits of ownership: A theory of vertical and lateral integration." Journal of Political Economy 94:691-719.

Hall, P. A., and D. Soskice

2001 "An introduction to varieties of capitalism." In P. A. Hall and D. Soskice (eds.), Varieties of Capitalism: The Institutional Foundations of Comparative Advantage: 1-68. Oxford: Oxford University Press.

Hall, P. A., and R. Taylor

1996 "Political science and the three new institutionalisms." Political Studies 44:936-958.

Hall, Richard H.

1992 "Taking things a bit too far: Some problems with emergent institutional theory." Issues, Theory, and Research in Industrial/Organizational Psychology:73-87.

\section{Handy, Daniel}

1916 "Anti-compact laws." In H. Brearley (ed.), The History of the National Board of Fire Underwriters: 282-296. New York: Frederick Stokes.

Hanson, Jon, Robert Dineen, and Michael Johnson

1974 Monitoring Competition: A Means of Regulating the Property and Liability Insurance Business. Milwaukee, WI: National Association of Insurance Commissioners.

\section{Hartman, Gerald}

1972 "New era of insurance rate regulation." Chartered Property and Casualty Underwriters Annals 25:153-162.

\section{Haveman, Heather, and $H$. Rao}

1997 "Structuring a theory of moral sentiments: Institutional and organizational coevolution in the early thrift industry." American Journal of Sociology 102:1606-1651.

\section{Hechter, Michael}

1987 Principles of Group Solidarity. Los Angeles: University of California Press.

\section{Heimer, Carol}

1985 Reactive Risk and Rational Action: Managing Moral Hazard in Insurance Contracts. Los Angeles: University of California Press.

1999 "Competing institutions: Law, medicine, and family in neonatal 
intensive care." Law and Society Review 1:17-66.

\section{Hensley, Roy}

1962 Competition, Regulation, and the Public Interest in Nonlife Insurance. Los Angeles: University of California Press.

Hobbs, Clarence W.

1942 "State regulation of insurance rates, part II." Proceedings of the Casualty Actuarial Society 28:344460.

Hoffman, Andrew

1999 "Institutional evolution and change: Environmentalism and the U.S. chemical industry." Academy of Management Journal 42:351-371.

Hoffman, Andrew, and Marc Ventresca

1999 "The institutional framing of policy debates." American Behavioral Scientist 42 (May):13681392.

Hollingsworth, J. Rogers

1997 "Continuities and changes in social systems of production." In J. R. Hollingsworth and R. Boyer (eds.), Contemporary Capitalism: The Embeddedness of Institutions: 265-310. Cambridge, UK: Cambridge University Press.

Hollingsworth, J. Rogers, and Wolfgang Streeck

1994 "Countries and sectors: Concluding remarks on performance, convergence, and competitiveness." In J. R. Hollingsworth, P. Schmitter, and W. Streeck (eds.), Governing Capitalist Economies: 270-300. Oxford: Oxford University Press.

\section{Immergut, Ellen}

1992 "The rules of the game: The logic of health policy-making in France, Switzerland, and Sweden." In S. Steinmo, Kathleen Thelen, and Frank Longstreth (eds.), Structuring Politics: 57-89. Cambridge, UK: Cambridge University Press.

Ingram, Paul

1998 "Changing the rules: Interests, organizations and institutional change in the U.S. hospitality industry." In Mary Brinton and Victor Nee (eds.), The New Institutionalism in Sociology: 258-276. Stanford, CA: Stanford University Press.

\section{Ingram, Paul, and Karen Clay}

2000 "The choice-within-constraints new institutionalism and implications for sociology." Annual Review of Sociology 26:525-546.

\section{Jordan, William}

1970 Airline Regulation in America: Effects and Imperfections. Baltimore,

\section{Joskow, Paul} MD: Johns Hopkins University Press.

1973 "Cartels, competition, and regulation in the property and insurance liability industry." Bell Journal of Economic and Management Science 4:375-427.

Joskow, Paul, and Nancy Rose

1989 "The effects of economic regulation." In R. Schmalensee and R. D. Willing (eds.), Handbook of Industrial Organization: 1450-1506. Elsevier Science.

\section{Kelly, Erin}

2003 "The strange history of employersponsored child care: Interested actors, uncertainty, and the transformation of law in organizational fields." American Journal of Sociology 109:606-649.

\section{Kenney, Roger}

1959 "Critique of the American agency system." In H. Wayne Snider (ed.), Readings in Property and Casualty Insurance: 265-275. Homewood, IL: Richard D. Irwin.

\section{Kenworthy, Lane}

1995 In Search of National Economic Success: Balancing Competition and Cooperation. London: Sage.

Kimball, Spencer, and Ronald Boyce

1958 "The Adequacy of rate regulation: The McCarran-Ferguson act in historical perspective." Michigan Law Review 56:545-578.

Kimball, Spencer, and Bartlett Jackson

1961 "The regulation of insurance marketing." Columbia Law Review 61:141200.

\section{Kingdon, John}

1984 Agendas, Alternatives, and Public Policies. New York: Harper Colllins.

Klein, Benjamin, Robert Crawford, and Armen Alchian

1978 "Vertical integration, appropriable rents, and the competitive contracting process." Journal of Law and Economics 21:297-326. 
Kleinman, Daniel, and Steven Vallas

2001 "Science, capitalism, and the rise of the 'knowledge worker': The changing structure of knowledge production in the United States." Theory and Society 30:451-492.

\section{Knight, Jack}

2001 "Explaining the rise of neoliberalism: The mechanisms of institutional change." In John Campbell and Ove Perderson (eds.), The Rise of Neoliberalism and the Institutional Analysis: 27-50. Princeton, NJ: Princeton University Press.

Knight, Jack, and Jean Emsinger

1998 "Conflict over changing social norms: Bargaining, conflict, ideology and eEnforcement." In Mary Brinton and Victor Nee (eds.), The New Institutionalism in Sociology: 105-126. Stanford, CA: Stanford University Press.

\section{Krasner, Stephen}

1984 "Approaches to the state: Alternative conceptions and historical dynamics." Comparative Politics 16:223-246.

Leblebici, Huseyin, Gerald Salancik, Anne Copay, and Tom King

1991 "Institutional change and the transformation of interorganizational fields: An organizational history of the U.S. broadcasting industry." Administrative Science Quarterly 36:333-363.

\section{Levi, Margaret}

1998 "Conscription: The price of leadership." In R. Bates, A. Greif, M. Levi, J. L. Rosenthal, and B. Weingast (eds.), Analytical Narratives: 108-147. Princeton, NJ: Princeton University Press.

Lilly, Claude

1976 "A history of insurance regulation in the United States." Chartered Property and Casualty Underwriters Annals 29 (June):99-115.

Lounsbury, M., Marc Ventresca, and Paul Hirsch

2003 "Social movements, field frames and industry emergence: A culturalpolitical perspective on U.S. recycling." Socio-Economic Review 1:71104.

Lusk, William, and Douglas Hibbard

1981 "The independent property-casualty agent distribution system." Char- tered Life Underwriters Journal 35 (January):10-19.

\section{McCraw, Thomas}

1984 Prophets of Regulation. Cambridge, MA: Belknap Press of Harvard University Press.

\section{Mehr, Robert}

1969 "Channels of distribution in insurance." Journal of Risk and Insurance 36:583-595.

\section{Meier, Kenneth}

1988 The Political Economy of Regulation: The Case of Insurance. Albany, NY: State University of New York Press.

Meyer, Alan

1982 "Adapting to environmental jolts." Administrative Science Quarterly 27:515-537.

Meyer, John, John Boli, George Thomas, and Francisco Ramirez

1997 "World society and the nationstate." American Journal of Sociology 103:144-181.

Mizruchi, Mark, and Lisa Fein

1999 "The social construction of organizational knowledge: A study in the uses of coercive, mimetic, and normative isomorphism." Administrative Science Quarterly 44:653-683.

Monteverde, Kirk, and David Teece

1982 "Supplier switching costs and vertical integration in the automobile industry." Bell Journal of Economics 13:206-213.

Morill, Thomas

1959 "Marketing revolution." In H. Wayne Snider (ed.), Readings in Property and Casualty Insurance: 49-56. Homewood, IL: Richard D. Irwin.

\section{Morrill, Calvin}

2005 "Institutional change and interstitial emergence: The growth of alternative dispute resolution in American law, 1965-1995. In W. Powell and D. Jones (eds.), How Institutions Change. Chicago: University of Chicago Press.

Moser, Henry

1950 "Operation of independents under the rate regulatory pattern." Law and Contemporary Problems 15:523-539.

\section{New York State}

1909-1911 "Hearings before the Joint Committee of the Senate and Assembly:1909-1911 (known 
as the "Merritt Hearings"). New York Assembly Documents, No. 30. Albany, NY: J. B. Lyon.

1911 "Report of the Joint Committee of the Senate and Assembly of the State of New York appointed to investigate the corrupt practices in connection with legislation and the affairs of insurance companies other than those doing life insurance business" (known as the "Merritt Report"). New York Assembly Documents, No. 30. Albany, NY: J. B. Lyon.

1922 "Intermediate Report of the Joint Legislative Committee on Housing. (known as the "Lockwood Report"). New York Legislative Documents, No. 60. Albany, NY: J. B. Lyon.

1924 "Sixty-fifth annual report of the Superintendent of Insurance." New York Legislative Documents, No. 21. Albany, NY: J. B. Lyons.

1925 "Sixty-sixth annual report of the Superintendent of Insurance." New York Legislative Documents, No. 21. Albany, NY: J. B. Lyons.

1932 "Seventy-third annual report of the Superintendent of Insurance." New York Legislative Documents, No. 33. Albany, NY: J. B. Lyons.

1969 The Public Interest Now in Property and Liability Insurance: A Report to Governor Nelson A. Rockefeller. New York: New York Insurance Department.

Noll, Roger

1985 "'Let them make toll calls': A state regulator's lament." American Economic Review 75:52-56.

1989 "Economic perspectives on the politics of collective action." In R. Schalmanesse and R. Willig (eds.), Handbook of Industrial Organization: 1254-1287. Amsterdam: Elsevier.

\section{Noll Roger, and Bruce Owen}

1983 The Political Economy of Deregulation. Washington, DC: American Enterprise Institute.

\section{North, Douglass}

1981 Structure and Change in Economic History. New York: W. W. Norton.

1989 "Institutional change and economic history." Journal of Institutional and Theoretical Economics 145:238-245.
1990 Institutions, Institutional Change and Economic Performance. Cambridge, UK: Cambridge University.

North, Douglass, and Barry Weingast

1989 "Constitutions and commitment: The evolution of institutions governing public choice in seventeenth century England." Journal of Economic History $69: 803-832$.

\section{Oliver, Christine}

1992 "The antecedents of deinstitutionalization." Organization Studies 13:563588.

Olson, Mancur

1971 The Logic of Collective Action. Cambridge, MA: Harvard University Press.

Orren, Karen, and Stephen Skowronek

1994 "Beyond the iconography of order: Notes for a 'New Institutionalism.", In Lawrence Dodd and Calvin Jilson (eds.), The Dynamics of American Politics. Boulder, CO: Westview.

\section{Ostrom, Elinor}

1990 Governing the Commons. Cambridge, UK: Cambridge University Press.

\section{Oviatt, F. C.}

1905 "History of fire insurance in the United States." In L. Zartman (ed.), Yale Readings in Insurance: 70-98. New Haven, CT: Yale University Press, 1921.

\section{Palmer, Don, and Brad Barber}

2001 "Challengers, elites and owning families: A social class theory of corporate acquisitions in the 1960s." Administrative Science Quarterly 1:87-140

\section{Parker, Kent}

1965 "Ratemaking in fire insurance." In J. Long and D. Gregg (ed.), Property and Insurance Liability Handbook: 169-189. Homewood IL: Richard D. Irwin.

Pauly, Mark, Hoard Kunreuther, and Paul Kleindorfer

1986 "Regulation and quality competition in the U.S. insurance industry." In J. Finsinger and M. Pauly (eds.), The Economics of Insurance Regulation: 65-107. New York: St. Martin's.

\section{Peltzman, Sam}

1976 "Toward a more general theory of regulation." Journal of Law and Economics 19:211-240. 
1989 "The economic theory of regulation after a decade of deregulation." In Brookings Papers: Microeconomics: 1-41. Washington, DC: Brookings Institution.

\section{Perrow, Charles}

2002 Organizing America: Wealth, Power and the Origins of Corporate Capitalism. Princeton, NJ: Princeton University Press.

\section{Posner, Richard}

1971 “Taxation by regulation.” Bell Journal of Economics and Management Science 2:22-50.

Powell, Walter, K. Koput, and L. SmithDoerr

1996 "Technological change and the locus of innovation: Networks of learning in biotechnology. Administrative Science Quarterly 41:116-145.

\section{Rao, Hayagreeva}

1998 "Caveat emptor: The construction of nonprofit watchdog organizations." American Journal of Sociology 4:912951.

\section{Riegel, Robert}

1916 Fire Underwriters Associations in the United States. New York: Chronicle.

\section{Rose, Michael}

1967 "State regulation of property and casualty rates." Ohio State Law Journal 28:669-733.

Roy, W. G.

1997 Socializing Capital. Princeton, NJ: Princeton University Press.

Sabel, Charles, and Jonathon Zeitlin

1997 "Stories, strategies, structures: Rethinking historical alternatives to mass production." In C. Sabel and J. Zeitlin (eds.), Worlds of Possibility: 1-33. Cambridge, UK: Cambridge University Press.

Samprone, Joseph, Jr.

1979 "Rate regulation and nonprice competition in the property and liability insurance industry." Journal of Risk and Insurance 46:683-696.

\section{Schneiberg, Marc}

1999 "Political and institutional conditions for governance by association: Private order and price controls in American fire insurance." Politics and Society 1 (March):67-103.

2002 "Organizational heterogeneity and the production of new forms: Poli- tics, social movements, and mutual Companies in American fire insurance, 1900-1930." Research in the Sociology of Organizations 19:3989.

\section{Schneiberg, Marc, and Tim Bartley}

2001 "Regulating American industries: Markets, politics and the institutional determinants of fire insurance regulation." American Journal of Sociology 1:101-146.

Schneiberg, Marc, and Elisabeth Clemens

2005 "The typical tools for the job: Research strategies in institutional analysis." In W. W. Powell and D. Jones (eds.), How Institutions Change. Chicago: University of Chicago Press.

Schneiberg, Marc, and J. Rogers Hollingsworth

1990 "Can transaction cost economics explain trade associations?" In M. Aoki, B. Gustafsson, and Oliver Williamson (eds.), The Firm as a Nexus of Treaties: 233-246. London: Sage.

Schneiberg, Marc, and Sarah Soule

2005 "Institutionalization as a contested, multilevel process: The case of rate regulation in American fire insurance." In Jerry Davis, Doug McAdam, Dick Scott, and Mayer Zald (eds.), Social Movements and Organization Theory: Building Bridges. Cambridge, UK: Cambridge University Press.

\section{Scott, W. Richard}

1994 "Institutional analysis: Variance and process theory approaches." In W. R. Scott, J. W. Meyer, and Associates (eds.), Institutional Environments and Organizations: 81-99. Thousand Oaks, CA: Sage.

Scott, W. Richard, Peter Mendel, Seth Pollock, and Carol Caronna

2000 Institutional Change and Healthcare Organizations. Chicago: University of Chicago Press.

\section{Sichel, Werner}

1966 "Fire insurance: Imperfectly regulated collusion." Journal of Risk and Insurance 33:95-114.

Sine, Wesley, and Robert David

2003 "Environmental jolts, institutional change, and the creation of entrepreneurial opportunity in the U.S. electric power industry." Research Policy 32:185-207. 
Skowronek, Stephen

1982 Building a New American State. Cambridge, UK: Cambridge University Press.

Snow, David, and Leon Anderson

1991 "Researching the homeless: The characteristic features and virtues of the case study." In Joe Feagin, Anthony Orum, and Gideon Sjoberg (eds.), A Case for the Case Study: 148173. Chapel Hill: University of North Carolina.

Snow, David, and Robert Benford

1988 "Ideology, frame resonance, and participant mobilization." International Social Movement Research 1:197-217.

Stearns, Linda Brewster, and Kenneth D. Allan

1996 "Economic behavior in institutional environments: The corporate merger wave of the 1980s." American Sociological Review 61:699-718.

Stigler, George

1971 "The theory of economic Regulation." Bell Journal of Economics and Management Science 2:3-21.

Strang, David, and John Meyer

1994 "Institutional conditions for diffusion." In W. R. Scott, J. W. Meyer, and Associates (eds.), Institutional Environments and Organizations: 100-112. Thousand Oaks, CA: Sage.

Strang, David, and Sarah Soule

1998 "Diffusion in organizations and social movements." Annual Review of Sociology 24:265-290.

Streeck, Wolfgang

1991 "On the institutional conditions for diversified quality production." In E. Matzner and W. Streeck (eds.), Beyond Keynesianism: 21-61. London: Elgar.

Streeck, Wolfgang, and Phillippe Schmitter

1985 "Community, market, State-and Association? The prospective contribution of interest governance to social order." In W. Streeck and P. Schmitter (eds.), Private Interest Government: 1-29. Beverly Hills, CA: Sage.

Streeck, Wolfgang, and Kozo Yamamura

2003 "Introduction: Convergence or diversity? Stability and change in German and Japanese capitalism." In K. Yamamura and W. Streeck (eds.), The End of Diversity? Prospects for
German and Japanese Capitalism: 150. Ithaca, NY: Cornell University Press.

Stryker, Robin

2000 "Legitimacy processes as institutional politics: Implications for theory and research in the sociology of organizations." In S. Bacharach and E. Lawler (eds.), Research in the Sociology of Organizations. Greenwich, CT: JAI.

\section{Suchman, Mark}

1995 "Managing legitimacy: Strategic and institutional approaches." Academy

\section{Tarrow, Sidney}

1994 Power in Movement. Cambridge, UK: Cambridge University Press.

\section{Thelen, Kathleen}

1999 "Historical institutionalism in comparative politics." Annual Review of Political Science 2:369-404.

Thelen, Kathleen, and Sven Steinmo

1992 "Historical institutionalism in comparative politics." In S. Steinmo, Kathleen Thelen, and Frank Longstreth (eds.), Structuring Politics: Historical Institutionalism in Comparative Analysis: 1-32. Cambridge, UK: Cambridge University Press.

\section{Thornton, Patricia}

2002 "The rise of the corporation in a craft industry: Conflict and conformity in institutional logics." Academy of Management Journal 45:81-101.

\section{U.S. Department of Justice}

1977 The Pricing and Marketing of Insurance. Washington, DC: U.S. Government Printing Office.

\section{U.S. Senate}

1961 "The insurance industry: Rates, rating organizations and state rate regulation." Congressional Report 831 . Washington, DC: U.S. Government Printing Office.

Vietor, Richard

1994 Contrived Competition: Regulation and Deregulation in America. Cambridge, MA: Belknap.

\section{Wandel, William}

1935 Control of Competition in Fire Insurance. Lancaster, UK: Art Printing.

Weingast, Barry, and William Marshall

1988 "The industrial organization of Congress; or, why legislatures, like firms, are not organized as markets." 
Journal of Political Economy 1:132163.

Weinstock, Sidney, and John Maloney

1971 "History and development of insurance law in California." West's Annotated Code. Vol. 42. St. Paul, MN: West.

\section{Western Underwriter}

Various years The Western Underwriter. Chicago: The Western Underwriter Company.

\section{Whitney, Simon}

1958 "Insurance." In S. Whitney (ed.), Antitrust Policies 2:342-381. New York: Twentieth Century Fund.

\section{Williamson, Oliver}

1975 Markets and Hierarchies. New York: Free.
1985 The Economic Institutions of Capitalism. New York: Free.

Wilson, James Q

1980 "The politics of regulation." In J. Q. Wilson (ed.), The Politics of Regulation: 357-394. New York: Basic Books.

\section{Yin, Robert}

1994 Case Study Research: Design and Methods. Thousand Oaks, CA: Sage.

\section{Zartman, Lester}

1909 "Discrimination and cooperation in fire insurance rating." In L. Zartman (ed.), Yale Readings in Insurance: 225-249. New Haven, CT: Yale University Press, 1921. 